\title{
The Heteronormativity Theory of Low Sexual Desire in Women Partnered with Men
}

\author{
Sari M. van Anders ${ }^{1,2,3} \cdot$ Debby Herbenick $^{4}$ - Lori A. Brotto ${ }^{5}$ Emily A. Harris ${ }^{1}$ Sara B. Chadwick ${ }^{6}$
}

Received: 21 May 2020 / Revised: 28 June 2021 / Accepted: 29 June 2021 / Published online: 23 August 2021

(c) The Author(s), under exclusive licence to Springer Science+Business Media, LLC, part of Springer Nature 2021

\begin{abstract}
Low sexual desire in women partnered with men is typically presumed to be a problem—one that exists in women and encourages a research agenda on causation and treatment targeting women. In this paper, we present a distinct way forward for research on low sexual desire in women partnered with men that attends to a more structural explanation: heteronormativity. A heteronormative worldview assumes that relationships and structures are heterosexual, gender (usually conflated with sex) is binary and complementary, and gender roles fit within narrow bounds including nurturant labor for women. We propose the heteronormativity theory of low sexual desire in women partnered with men, arguing that heteronormative gender inequities are contributing factors. We outline four hypotheses and their predictions related to: inequitable divisions of household labor, blurring of partner and mother roles, objectification of women, and gender norms surrounding sexual initiation. We discuss some mechanisms—social, physiological, and otherwise - for the heteronormativity theory, especially related to stress, objectification, and nurturance. We close by noting some limitations of our paper and the ways that the heteronormativity theory of low sexual desire in women partnered with men provides a rigorous, generative, and empirical way forward.
\end{abstract}

Keywords Sexual desire $\cdot$ Heteronormativity $\cdot$ Gender roles $\cdot$ Femininity $\cdot$ Household labor $\cdot$ Nurturance

\section{Introduction}

In this article, we propose the heteronormativity theory of low sexual desire in women partnered with men. In doing so, we aim to provide an empirically-grounded approach to low desire and avenues for further research that takes relationships, genders, and inequity into account. We discuss sexual desire-what it is, what low desire is, whether low desire is a problem and,

Sari M. van Anders sva5@queensu.ca

1 Department of Psychology, Queen's University, 62 Arch Street, Kingston, ON K7L 3N6, Canada

2 Department of Gender Studies, Queen's University, Kingston, ON, Canada

3 Centre for Neuroscience Studies, Queen's University, Kingston, ON, Canada

4 School of Public Health, Indiana University, Bloomington, IN, USA

5 Department of Obstetrics and Gynaecology, University of British Columbia, Vancouver, BC, Canada

6 Departments of Psychology and Women's and Gender Studies, University of Michigan, Ann Arbor, MI, USA if so, why, where, and for whom-and then discuss specific hypotheses and predictions derived from our theory. Within these hypotheses, we discuss a number of mechanisms, including objectification. We follow that with discussions of potential physiological pathways and then our conclusions. To begin, we present a case study from one of the co-author's clinical practice that exemplifies how contextual factors can contribute to low desire, but are often ignored in favor of individual-based, biomedical solutions.

\section{A Case Study of One Woman's “Low" Sexual Desire}

Denise is fairly representative of women seeking treatment for her perceived loss of sexual desire and certainly is not an outlier. ${ }^{1}$ She is 42 , has been married for 15 years, and worked full-time managing pastoral services in a large hospital. She sought treatment in a major medicine treatment center after complaining of a very low level of sexual desire for the past two years, following the birth of fraternal twins. Denise and her husband, James, had struggled with infertility for 7 years before the successful conception from in vitro fertilization. ${ }^{1}$ Over those 7 years, Denise became engrossed in tracking her

\footnotetext{
${ }^{1}$ Names are pseudonyms.
} 
monthly ovulation cycle, in making sure that intercourse happened at least once during her ovulation period, and-like many - she had an elaborate series of activities following sex to help ensure the successful implantation of the fertilized egg. Sex became focused exclusively on reproduction. Their previously enjoyed foreplay activities ceased altogether, and neither experienced much, if any, satisfaction following these ritualized encounters. Since the birth of the twins, Denise felt a great sense of loss after leaving her previously rewarding job, James' work increased in duration to compensate for the shift in income, and Denise's identity as a mother superseded any sense of herself as a partner or lover. She lost desire for sex and for James completely and perceived his requests for sex as intrusive; they were yet another demand placed upon her following a full day of devoting herself to her two demanding children who slept no longer than 4-h intervals through the night, even now at 22 months old. James withdrew from childcare and household chores and activities, in part due to exhaustion following his 14-h work days and in part to "punish" Denise for withholding sex from him. She resented him for expecting that she would be the sole caretaker for their children, and lost attraction for him as he increasingly retreated to online gaming late at night after the twins were asleep. They almost never went to sleep at the same time of night. Conversations were centered around issues of the children or their financial situation. The topic of sex was avoided because it resulted in Denise feeling like she was responsible for their current situation. Denise felt considerable distress over the situation-both for a concern about hurting James, but also because it left her feeling incomplete sexually, and like she was truly missing out on an experience that she perceived most other women were enjoying.

They decided to seek out sex therapy after Denise's family doctor identified their sexual disconnection as a potent stressor on her life. A thorough assessment by a sex therapist led Denise to vocalize her criticisms of James. She verbally berated him for "going flappy" during intercourse attempts; he responded by blaming her for being too critical of him. The layers of their sexual and relational strain were numerous and palpable. And yet, as they went to leave the end of their first session with the therapist, James turned to the provider and asked, point-blank, whether she thought that "the female Viagra" could help solve their woes.

This case study is one example of the issues plaguing perceptions of low sexual desire in women partnered with men. That is, while James and Denise's situation seems an obvious example of contextually-determined low desire, James ascribed the problem to a biological dysfunction in Denise's body. The idea that low desire rests in the individual reflects an essentialist view of sexuality that has been advanced by the medical field for decades and cogently critiqued (Tiefer, 2001, 2004). As such, James' reaction is not particularly surprising or uncommon.
In essentialist views of sexuality, sexual desire is considered an innate and universal part of human biology. It is assumed to be built into all people, as it is into non-human animals, by evolutionary forces that drive us to reproduce (Tiefer, 2004). Guided by these assumptions, medical approaches have framed sexual desire as a result of physiological processes that are essential to "normal" human functioning and survival. Accordingly, problems like "low" desire have been framed as a result of physical dysfunctions within individuals (Tiefer, 2004). In support, many current medical classification systems would align with James' reaction and label Denise and James' situation as a result of something awry in Denise. For example, the Diagnostic and Statistical Manual of Mental Disorders (5th ed.; DSM-5; American Psychiatric Association, 2013)—which includes "Female Sexual Interest/Arousal Disorder" diagnosis-defines a diagnosable disorder as "a syndrome characterized by clinically significant disturbance in an individual's cognition, emotional regulation, or behavior that reflects a dysfunction in the psychological, biological, or developmental processes underlying mental functioning" (American Psychiatric Association, 2013, p. 20). This means that, even if a clinician acknowledges that interpersonal factors within James and Denise's relationship contribute to their discrepancies in desire, only an individual-i.e., Denise — can receive the diagnosis, and so only something within Denise would be labeled as dysfunctional.

But why have essentialist, medicalized views of sexuality come to monopolize how people understand low sexual desire? One argument is neoliberal - that locating the problem of low desire in individuals' bodies has high financial stakes (Hartley $\&$ Tiefer, 2003; Tiefer, 2000b). ${ }^{2}$ Naming low desire as an individualized biological dysfunction creates a demand for biological (i.e., medical) solutions; thus, pharmaceutical companies stand to gain by selling a "treatment." It is therefore perhaps no surprise that those with a vested interest in the DSM-5 criteria for sexual dysfunctions sometimes have strong ties to the pharmaceutical industry or that this industry has invested millions of dollars into making sure that lay-people like James see "the female Viagra" as the most logical (and purchasable) solution to their sexual problems (Meixel et al., 2015). ${ }^{3}$

Locating problems in physiological parameters can be an improvement over sin or morality-based lenses (though factors

\footnotetext{
2 According to Bay-Cheng (2015), neoliberalism is most commonly associated with macroeconomic and social policies that open markets, deregulate industry, and abandon social welfare. But, it has come to permeate popular culture and discourse by championing tropes of personal empowerment that position women as fully responsible for achieving — often through purchasable means - their own sexual ideals (which are in actuality generally shaped by society).

${ }^{3}$ We note that this likely does not apply to people on the DSM-5 committee, who are screened for conflicts of interest, but to those who otherwise rely on and use the DSM-5.
} 
related to health are often understood through sin- and moralitybased lenses, as well as physiology). Yet contextual problems are not simple or quick to solve, which makes the idea of an easy-to-take pill a more attractive option (Tiefer, 2004). For example, in the case of James and Denise, writing off low sexual desire as a problem within Denise's body positions the problem as out of James' control, disconnecting it from his own behaviors. He can therefore continue to presume that Denise will be the sole caretaker of their children and he can play video games as he pleases, all with no expectations for him to attend to the couple's sexual issues or their divisions of labor.

Of course, this is not to say that everyone holds essentialist, medicalized views of desire. Many current conceptualizations of desire suggest that low desire is shaped by the unique interpersonal dynamics of a given relationship, and there is evidence that this perspective is growing. For example, the DSM-5 diagnostic guidelines for Female Sexual Interest/ Arousal Disorder outline that clinicians should consider partner factors (e.g., partner's sexual problems, partner's health status), relationship factors (e.g., poor communication), individual vulnerability factors and stressors (e.g., emotional abuse, job loss), and medical factors as important contributors (American Psychiatric Association, 2013, pp. 434-435). This is certainly an improvement over previous versions of the DSM, which did not include suggested assessments of nonmedical correlates (American Psychiatric Association, 2013, p. 814). But, as we mentioned previously, this still locates the diagnosis in the individual, with other factors as something that impacts the process. And, it avoids structural issues by individualizing even the relational and cultural factors.

However, James and Denise's situation is not unique. It reflects what has become a suspiciously common pattern in women's relationships with men more broadly, where a woman's sexual desire disappears and/or becomes "too low" and then is deemed a dysfunction within the woman. This pattern is suspicious because the numbers of women reporting low desire are so high that they might be modal, if not ordinary; and, they are certainly too high to reflect individual pathologies within individual women's bodies (Richgels, 1992). It is also suspicious because many women who report low sexual desire describe considerably similar interpersonal problems with their men partners (Sims \& Meana, 2010; Trudel et al., 2001). Thus, while low desire is likely not an individual problem within Denise' body, the issues and inequities it results from are also likely not an individual problem within James or the interpersonal dynamics of James' and Denise's specific relationship. Instead, we turn to a structural level explanation: gender norms, following other foundational work (e.g., Tiefer, 2001). In this paper, we explore how gender norms as a social structure could explain low desire in women partnered with men.

Gender norms are clearly at play for desire in both Denise and James - as they are for desire in women, men, and people of all gender/sexes and sexualities (gender/sex/ualities). ${ }^{4}$ But gender norms vary in their content, applicability, and uptake, and thus do not operate in the same way across all gender/sex/ualities (Connell \& Messerschmidt, 2005; Jackson, 2006; Sanchez et al., 2012; Schippers, 2007; Wiederman, 2005). Accordingly, in this paper, we focus on one group: women partnered with men, though others may look elsewhere. Women partnered with men are heterogeneous themselves, with differing relations to oppression and privilege that shape the gender norms they experience, and how those norms shape their lives (Armstrong et al., 2014; Bay-Cheng, 2015; Bettie, 2000; Schippers, 2007). Still, this is a starting point, and we argue that social norms related to gender are key to a rigorous, generative, and empirical approach to research and understanding about low sexual desire in women partnered with men.

\section{What Is Sexual Desire?}

Sexual desire is often framed as a natural drive, especially toward experiencing orgasm or genital and bodily pleasure (Basson, 2002a; DeLamater \& Hyde, 1998; Jackson \& Scott, 2002; Tiefer, 2004; Tolman \& Diamond, 2001; Wood et al., 2006). As we mentioned previously, this drive for pleasure is largely situated as innate, occurring within biological bodies, and reflecting internal, physiological mechanisms. With this view, desire is generally thought to occur spontaneously from within the body, in the sense that it needs no external cues. Sexuality is broadly understood as a cycle that begins with desire, which leads to sexual activities, which carry pleasure and lead to orgasm (Masters \& Johnson, 1966).

More contemporary approaches frame sexual desire in varied ways. One is that desire may be a response to pleasure and arousal or even the same phenomenon as arousal itself (Basson, 2001a, 2001b, 2002b). Another is that sexual desire is multifaceted and can reflect not only desire for orgasm or bodily pleasure, but desire for closeness, power, relaxation, etc. (Chadwick et al., 2017a, 2017b; Goldhammer \& McCabe, 2011; Mark et al., 2014; Raisanen et al., 2018; van Anders, 2012, 2013; van Anders et al., 2011). With multifaceted desire, desire can be partnered or solitary, vary in degree and kind, and its presence or absence is neither natural nor unnatural, but reflective of a host of situational and psychological factors.

Still another contemporary framing of desire is the incentive motivation model (Toates, 2009). This model holds that sexual arousal and desire are influenced by people's reasons for sex, attention to relevant stimuli, and contextual factors. Further, the model suggests that arousal and desire arise simultaneously and

\footnotetext{
${ }^{4}$ We use "gender/sex" to refer to women, men, and nonbinary people; whole people, identities, and factors that can (but do not have to) reflect an entanglement of gender (sociocultural factors) and sex (bodily and evolved factors) (van Anders, 2015; van Anders \& Dunn, 2009). We use "gender/sex/uality" to refer to the mix or entanglement of gender, sex, and sexuality.
} 
reinforce one another. This model emphasizes the importance of relevant (or competent) sexual cues to elicit arousal; thus, problems with desire can often be linked back to ineffective stimuli in the woman's life.

Taken together, these different perspectives on what sexual desire actually is suggest that there is no one definition of sexual desire. As such, it perhaps makes sense that researchers have attempted to measure sexual desire in varying ways. For example, the Female Sexual Function Index (FSFI) focuses on frequency and intensity of "feeling sexual desire" (Rosen et al., 2000), whereas the Changes in Sexual Functioning Questionnaire uses a multidimensional assessment of sexual frequency, frequency of fantasies, enjoyment with erotic material, and pleasure when thinking about sex (Clayton, McGarvey \& Clavet, 1997). Measures like the Sexual Desire Inventory (SDI; Spector et al., 1996) separate desire into dyadic (i.e., the desire for partnered sexual activity) and solitary (i.e., the desire to be sexual alone), and assess these constructs via questions related to how often individuals would have liked to engage in dyadic or solitary sexual activities, individuals' frequency of sexual thoughts, and the strength and importance of sexual desire within the last month. That sexual desire is conceptualized and measured in different ways certainly has implications for our theorizing about low desire in women partnered with men but, for now, we refer to desire broadly as the desire to engage in sexual activity. This definition is purposefully vague because what clinicians and researchers mean by "desire" when studying it in women is vague despite the general consensus that not having enough is a problem, and it is possible that our theory may be relevant for all or only some of the ways that sexual desire is conceptualized (and we wish to stay open to these possibilities).

\section{What Is "Low" Desire?}

Given that sexual desire in itself does not have one universallyaccepted definition, it perhaps follows that low desire does not have one universally-accepted definition either, though it might be understood as desire that is lower than some bound. That bound, of course, is subjectively set since there is no natural demarcation between desire that is low versus within ranges thought to be normative or typical (Richgels, 1992; Tolman \& Diamond, 2001; Wood et al., 2006).

Approximately $30 \%$ of women are reported to experience low desire (Fugl-Meyer \& Fugl-Meyer, 2002; Laumann et al., 2005 ) with estimates ranging from $10.2 \%$ up to $55 \%$ (Mercer et al., 2003; Witting et al., 2008). For men, the numbers range from 1 to 28\% (Brotto, 2010a, 2010b; Frank et al., 1978; Laumann et al., 1999, 2005; Lindau et al., 2007). Interestingly, dyadic research shows that, in mixed-gender/sex couples, women and men are equally likely to be the lower desire partner (Davies et al., 1999; Mark \& Murray, 2012) and that low desire in men and women can exist at overlapping levels (Brotto, 2010b; McCabe et al., 2016).

Desire is often situated as low because of its relative status to a partner's level of desire. Interestingly, however, this is not a gender-neutral process and the bound is often set with the man partner as reference point (Ling \& Kasket, 2016; Richgels, 1992; Tiefer, 2000a; Wood et al., 2006). Accordingly, when a woman experiences lower desire than a man partner, her desire is often labeled low. In the converse situation, however, men are still the referent: in the case of a man reporting lower desire than a woman partner, the woman's desire is labeled too high (e.g., they are labeled insatiable or "sluts" in negative ways), rather than the man's desire being labeled too low (Crawford \& Popp, 2003; Farvid et al., 2016; Tolman, 1994; Wiederman, 2005). This highlights the gendered subjectivity inherent to conceptualizations of low desire, where low desire is most often seen as residing not just in bodies, but in women's bodies relative to men's desires.

\section{Is Low Desire a Problem? Why? For Whom? Where?}

Low desire is typically seen as a problem residing in peoples' - usually women's - bodies in part because sexual desire is seen as a natural and human universal. This assumption is prominent within both academic and public discourse. But, is low desire really a problem? In some ways, believing that low desire is necessarily a problem is inaccurate and belies empirical evidence. This view of low desire as a problem ignores that it is common for people's sexual desire to ebb and flow (Ridley et al., 2006) and that many life phases involve, or even are characterized by, low desire (Dawson \& Chivers, 2014). In addition, Asexual individuals have increasingly helped academics and the public understand that low or no sexual desire for other individuals is a part of human diversity (Brotto \& Yule, 2017; Cerankowski \& Milks, 2010; Chasin, 2013; Hinderliter, 2013). Similarly, Demisexual individuals have made clear that some aspects of desire can only emerge when other relational needs are met (Decker, 2015; Galupo et al., 2014). Yet low desire within non-Asexual individuals continues to be seen as a problem rather than as a part of sexual diversity. Why would low desire be a problem and for whom?

One reason that low desire in women may be considered a problem is because women report distress associated with it. Indeed, distress is one of the defining features in diagnosing a desire disorder in the DSM-5 (American Psychiatric Association, 2013; Frost \& Donovan, 2015; Wakefield, 1997), though where this distress comes from is an issue we explore more below. Another reason is that most research on low desire tends to come from clinical and health researchers who frame low desire as a problem. For example, using terms like "incidence of low desire" or "risk of low desire" make clear that low desire is seen as a disease-like state or at least an unwanted condition. 
Another reason why low desire is a problem may be that desire serves an important function that its absence impedes. That is, in many countries, women's desire has become an important doorway to sex, in contrast to times and places where structures of power have deemed it irrelevant. For example, in the past, being a wife or sex worker was (though sometimes still is) seen as consent by husbands, clients, and legal structures (Humphreys, 2007; Margolin et al., 1989; Monson et al., 2000; Russell, 1990; Sullivan, 2007) and Western nations have only recently defined rape as possible within marriage (Jackson, 2015; Russell, 1990). But, consent between partners is increasingly understood to involve not only the absence of " $n o$ " but the presence of "yes," ideally reflecting desire (Dougherty, 2015). Accordingly, many men who want to have sex with women (hopefully) seek a desirous yes as consent. However, this can provide a very progressive approach to a very old goal: getting women to have more sex with men, rather than helping women have better and more pleasurable sex and relationships or the ability to be nonsexual when one is uninterested in sex (Fahs, 2010, 2014a). Taken together, absence of desire in women could therefore be a "problem" because it interferes with changing standards, including legal ones, around sexual consent and thus sexual access for men.

An additional reason that low desire might be a problem relates to the specter of "false advertising." A common trope is that women are —or act—sexually interested and available to men partners before commitment or marriage but not after (McNulty et al., 2019), specifically to secure this commitment. Women do report a decrease in desire over relationships with men (Murray \& Milhausen, 2012), but it may be that this reflects a problem that occurs in committed relationships rather than necessarily in women themselves. For example, when relationships shift from low to high commitment/interdependency (e.g., shifting from dating to cohabiting), most - including feminist - women are surprised by the men's lack of participation in housework (Baker, 2012; Baxter, 2005; Baxter et al., 2008; Davis et al., 2007; Shelton \& John, 1993). Men's failed promise of equitable partnering practices could negatively impact women's desire, such that the problem is false advertising after all—of a different kind. Arguing, in these contexts, that low desire is a problem within women sidesteps the need to attend to gender dynamics and inequities.

As listed here and beyond, there are a number of reasons low desire might be seen as a problem. Research tends to focus on low desire as a problem in women and, specifically, in women partnered with men. Certainly, many women want to want their men partners more. And, many men want their women partners to want more sex with them. But women partnered with men are not the only group reporting low desire (Brotto, 2010b; Nichols, 1983, 1988). The focus on women partnered with men, then, reveals that the public, academic, and health concerns with "low desire" may actually be more accurately pinpointed as concerns with "low desire in women partnered with men."

\section{Approaches to Low Desire}

Given that low desire in women is often considered a problem (by medical professionals, researchers, men partners, and women with low desire), researchers have attempted to develop ways to treat it. Importantly, research on treatments and whether they are successful can provide insights into what causes (or does not cause) a given problem. Below, we review some of the approaches to treating low desire in women partnered with men and consider what the findings tell us (or do not tell us) about possible contributing factors in sexual desire.

\section{Biomedical Approaches to Low Desire}

Biomedical approaches to low desire in women partnered with men have tended to focus on hormones, especially androgens like testosterone. Androgens are a class of steroid hormones released from the testes and ovaries, as well as the adrenal gland (better known for stress and cortisol) and more. Testosterone is broadly assumed to cause and fix low desire, likely because researchers have long assumed that it accounts for behavioral phenomena that men score higher on than women (Karkazis \& Jordan-Young, 2015; van Anders, 2013). These assumptions are curious because research does not support them. While testosterone is linked to desire in complex and nuanced ways (Chadwick et al., 2017b; Hintikka et al., 2009; Jockenhövel et al., 2009; Raisanen et al., 2018; van Anders, 2012; van Anders et al., 2011), it accounts for neither gender/sex differences in desire nor low desire in women with clinical diagnoses of low desire (Basson et al., 2010; Davis, 2005; Raisanen et al., 2018; Schreiner-Engel et al., 1989; van Anders, 2012; van Anders \& Dunn, 2009; van Anders et al., 2007a, 2014).

Researchers have also looked to other biomedical causes of low desire. Some have considered estrogens (Cappelletti $\&$ Wallen, 2016). Others have turned to neurotransmitters, like the drug Flibanserin (Jaspers et al., 2016). Flibanserin increases levels of dopamine and norepinephrine, which are thought to increase sexual arousal, and decreases serotonin, which is thought to inhibit sexual arousal (Pfaus, 2009; Stahl et al., 2011). However, there is little evidence to support these biomedical factors as effective treatments or as causes of low sexual desire. Researchers studying estrogens have generally characterized them as related to vaginal lubrication or vasocongestion rather than desire (Sarrel, 1998; Shen et al., 1999). And, drugs like Flibanserin have been shown to have extraordinarily minimal effects by clinical or real-life standards: one extra satisfying sex event every two months (conflating satisfaction and desire) and a 0.3 increase in self-reported desire on a 5-point scale (Jaspers et al., 2016).

Biological fixes do not work, yet the belief that sexual desire is caused by biological causes remains unaffected: why? One reason is biologism or "bio/logics," beliefs that biology must be the real and only cause for all human phenomena 
(Fausto-Sterling, 2000; van Anders, 2014). Another is that the empirical data that fail to support the status quo are often ignored. Some have called this an "awkward surplus of knowledge," which people do not deny but also do not incorporate into their beliefs about the world (Fujimura, 2006). Some might use the term "zombie fact" - for example about the belief that testosterone causes most gender/sex differences including desire, because this belief refuses to die even when killed, i.e., faced with disconfirmatory facts (Jordan-Young \& Karkazis, 2019). We might call this sidelining of data "faith-based" science, where beliefs are held in ways that oppose data and impact science and public discussions. The faith-based science of zombie facts matters when it comes to biological fixes for low desire in women partnered with men, because it is arguably reminiscent of The Stepford Wives (Levin, 1972)_tinkering with the internal mechanics of women's bodies in pursuit of men's pleasure and contentment. It also matters because it provides a misguided roadmap for the science of low desire in women partnered with men.

Of course, we are not saying that biology has nothing to do with sexual desire; our critique is that biomedical approaches that position desire as an innately-driven phenomenon continue to dominate discourse surrounding desire in unsupported ways, as argued by Leonore Tiefer (e.g., 2001). Later, we will discuss what it can look like to reframe biological conceptualizations of sexual desire in ways that attend to-rather than ignorecontextual influences on desire.

\section{Psychological Therapy Approaches to Low Desire}

Another approach to treating low desire is psychological therapy. One psychological therapy method that shows some success, unlike biomedical approaches, addresses and attempts to alter women's cognitive associations with sex. For example, mindfulness-based therapy involves cultivating skills toward increasing attention to the present moment, and developing non-judgmental and compassionate acceptance of one's current experiences. Several non-controlled studies have evaluated mindfulness as a treatment for low desire, and a meta-analysis has shown moderate to large effect sizes for the primary endpoint of low desire (Stephenson \& Kerth, 2017). At first glance, the success of mindfulness-based therapy could seem to pinpoint low desire as an issue in women's minds rather than their bodies, fitting with approaches that locate the problem of low desire in individual women.

A closer look at mindfulness-based therapy suggests that there is more to the story of women's low desire than locating it in their minds. Researchers have theorized that mindfulnessbased therapy helps women's desire because attention to and acceptance of the present moment (fundamental elements of mindfulness) lessen cognitive behaviors that inhibit arousal and desire (Brotto et al., 2016; Brotto \& Basson, 2014; Leavitt et al., 2021; Pepping et al., 2018); notably, many of these cognitive behaviors are connected to gendered expectations for women. For example, mindfulness-based therapy can help lessen the tendency to self-criticize, which is itself connected to cultural pressures for women to meet unobtainable beauty standards (Fredrickson \& Roberts, 1997; Schick et al., 2010; Woertman \& Brink, 2012). Mindfulness-based therapy can also lessen women's tendency to evaluate their sexual responsiveness, which is tied to gendered sexual scripts that women must experience (or perform) arousal and pleasure or else fail to satisfy men partners (Cacchioni, 2007; Frith, 2013; Nicolson \& Burr, 2003; Nobre \& Pinto-Gouveia, 2008). Mindfulness-based therapy can also lessen women's tendency to follow distracting thoughts, many of which relate to the extensive chore lists that stem from prescriptive gender roles for women (Bodenmann et al., 2006; Hamilton \& Julian, 2014; Hochschild \& Machung, 1989; Sims \& Meana, 2010). Accordingly, mindfulness-based therapy may be an effective treatment for low desire in women partnered with men-not because it fixes women's psychological problems, innate or not-but because it happens to address the negative side effects of gendered structures that shape women's lives more broadly.

Psychological therapy has also used couples therapy to approach low desire in women partnered with men as an interpersonal or relationship problem. One particularly effective strategy for treating low desire in women through couples therapy is the use of cognitive behavioral therapy (CBT) (Günzler \& Berner, 2012). CBT addresses maladaptive thoughts and avoidance behaviors and the focus in couples therapy related to women's low desire usually involves behavioral training to improve communication between partners, increase sexual intimacy and skills, and reduce sexual and performance anxiety. A meta-analysis of mostly CBT approaches for low desire (Frühauf et al., 2013) found an overall large effect size of CBT compared to wait-list or other treatments (Cohen's $d=0.91$ ) for the primary endpoint of low desire.

The CBT research expands attributions of women's low desire to relationship dynamics, which is an improvement from locating low desire in women as individuals. As with mindfulness-based therapy, however, a closer look at the CBT findings also connects low desire in women partnered with men to larger, structural problems related to gender. For example, in a CBT couples therapy study to treat women's low desire, researchers first assessed women's attributions of their desire problems (Trudel et al., 2001). These attributions-such as anxiety about partners' negative reactions to sexual refusals, a lack of sexual pleasure, feelings of sexual guilt and shame, and feeling like their partner treats them as a sex object-are arguably tied to gendered sexual scripts (Trudel et al., 2001; Wiederman, 2005). The efficacy of CBT for low desire in women partnered with men may therefore rely on treating the negative side effects of gendered structures; in this case, those that foster dysfunctional interpersonal dynamics between women and men partners more broadly. 


\section{Evidence for a Structural Approach to Low Desire}

Biomedical and psychological therapy approaches have offered meaningful insights into what does or does not cause low desire in women partnered with men. For example, biomedical approaches have perhaps taught us that low desire is not caused by women's dysfunctional bodies, despite common beliefs that sexual desire is a spontaneous, natural urge driven by hormones or other physiological parameters. In contrast, the relative success of some psychological therapy approaches in treating low desire in women has perhaps taught us that low desire is somehow connected to individuals' psychological processes and/or the dynamics of interpersonal relationships. Research could stop there (and arguably, until now, it largely has), but a closer look at psychological therapy approaches calls to question: what causes the psychological processes or interpersonal dynamics that contribute to low desire in women in the first place? And, why do so many women happen to have the same desire-inhibiting cognitive dysfunctions or interpersonal problems with their men partners? As we suggested, a viable explanation for these patterns in low desire in women partnered with men is a structural one, leading us to propose a new theory: that heteronormative gender roles and norms cause low desire in women partnered with men.

\section{The Heteronormativity Theory of Low Sexual Desire in Women Partnered with Men}

\section{What Is Heteronormativity?}

Heteronormativity refers to sets of structures and beliefs and about gender/sex and sexuality. These position heterosexuality as normal, regular, healthy, universal, and desired in general, and specifically over bisexual, lesbian, and gay sexualities among other minoritized existences (Warner, 1991). And, heteronormativity relies on a gender binary that positions men and women as naturally different, complementary, and opposites, though not equals, and as reproductive partners (Jackson, 2006; Schilt \& Westbrook, 2009).

Heteronormative gender roles differ for women and men in ways that are the foundation of our theory. What are these gender roles? For women, these include absence of sexual motivation and provision of nurturance (e.g., social, emotional, and instrumental support to others) whereas, for men, they include high sexual interest, dominance, and competent independence (Eagly, 1987; Eagly \& Wood, 1999; Glick \& Fiske, 1996; Jackman, 1994; Levant \& Richmond, 2008; Lorber, 1994; O’Neil, 2008; Wiederman, 2005; Wood \& Eagly, 2002). Though most people blend these traits, these social roles are prevalent and straying from them carries consequences (Duckitt, 1994; Eagly, 1987; Eagly \& Wood, 1999; Hyde, 2005, 2006). Policed at individual and structural levels, penalties for breaking gender norms can include stigma, derogatory labeling as "slut" or "prude," relationship dissolution, and much more (Bay-Cheng, 2015; Butler, 2011; Cooke, 2006; Crawford \& Popp, 2003; Fahs, 2011; Farvid et al., 2016; Meyer, 2003; Schilt \& Westbrook, 2009; West \& Zimmerman, 1987; Wood \& Eagly, 2012). Despite these social pushes and pulls, these roles are widely seen as reflecting natural divisions of existence and labor, and this assumption of naturality is a hallmark of heteronormativity.

Heteronormativity in gender inequities clearly overlaps with sexism. Sexism includes discriminatory and/or prejudicial behavior, attitudes, and structures on the basis of gender/ sex. It disproportionately targets and harms women, femininity, and/or femaleness, yet polices people of all gender/sexes. Why do we focus on heteronormativity rather than sexism? Because sexism values features tied to men, masculinity, and maleness, whereas heteronormativity positions people within a narrowly defined, binary gender/sex rooted in reproduction.

In addition to sexism, heteronormativity in gender roles overlaps with heterosexuality. Heterosexuality might be understood to reflect sexual (nurturant and/or erotic) orientations, behaviors, and identities built around mixed-gender/sex connection, usually understood to be between women and men. Why do we focus on heteronormativity rather than heterosexuality? Because heterosexuality is arguably descriptive and does not, itself, operationalize itself as normal, natural, legal, and preferred or even rooted in biological sex binaries, whereas heteronormativity is what does this to heterosexuality, eschewing diversity for complementary binary procreative beings.

\section{Why Focus on How Heteronormativity Affects Women Partnered with Men?}

Heteronormativity was put forward largely by queer and/or sexual minority scholars to make visible how positioning heterosexuality as the natural norm invisibilizes and/or marginalizes minority sexualities (Butler, 1996; Rich, 1980; Rubin, 1984; Sedgwick, 1990; Warner, 1991). So, while heteronormativity constrains people of all gender/sexes and sexualities, using heteronormativity in a theory that focuses on women partnered with men can be fraught. Heteronormativity engenders oppressions that have disproportionate impacts on sexual minorities, and focusing it on women partnered with men could elide that. ${ }^{5}$ Yet the explanatory power of heteronormativity reaches sexual majorities as well.

A focus on low desire in women partnered with men is problematic not least because it could be a malappropriation of heteronormativity. Why focus on women, where the problem has been "located" for so long? Why not focus on the ways that heteronormativity could be a valuable lens for understanding low desire in people of various gender/sexes, sexualities,

\footnotetext{
5 We use minorities to refer to a marginalized position in a power hierarchy, not as a statistical term (van Anders, 2015).
} 
Fig. 1 Heteronormativity contributes to low sexual desire in women partnered with men, in at least four ways

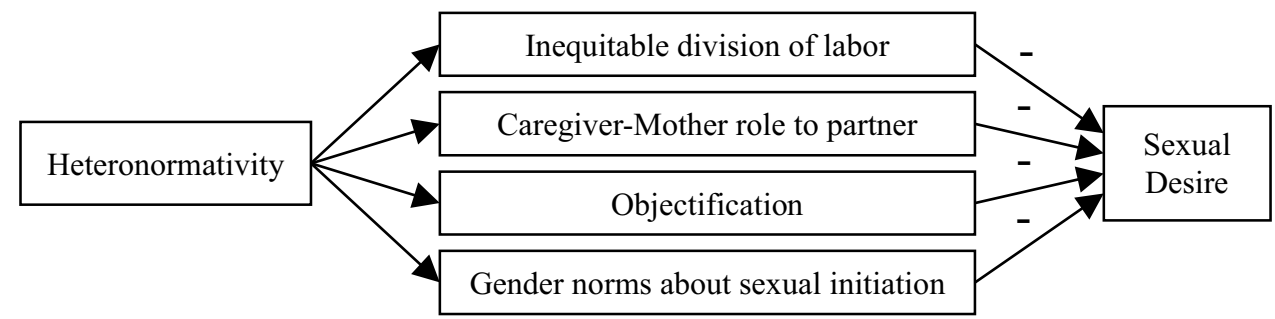

and relationalities — including but beyond men partnered with women? One reason is that the vast majority of research and public discussion has been on low desire in women partnered with men (for reviews, see Brotto, 2010a, 2010b) (but see also work beyond this gender/sex group, e.g., Nichols, 1988, 1995; Olson-Kennedy et al., 2016). We therefore follow this group where the "problem" has been located. Yet we know that these questions are important across gender/sex and sexual diversity, and anticipate that our theory will be useful when adapted and/ or constructed in ways meaningful beyond women partnered with men.

Finally, our focus on women partnered with men raises a fundamental question: which women? Research on low desire in women partnered with men has focused on samples that are in actuality or presumptuously cisgender, heterosexual, monoamorous, and within "reproductive" age, among other majoritarian social locations. And, of course, women partnered with men exist within inequitable social structures that have intersecting axes of identity that matter for theorizing about impacts of heteronormativity, including race/ethnicity, dis/ability, and socioeconomic status (Clare, 2015; Crenshaw, 1993; Hoskin, 2017; Hudson, 2019; Jagose, 1996; Settles \& Buchanan, 2014; Settles et al., 2008; van Anders, 2015). "Women" unqualified is often used as a placeholder for majority women. It is possible that this paper applies only or mostly to women who have some level of privilege and access to resources, and it may be that it is relevant beyond other majority social locations or it may be limited in its application. "Which women" is therefore not only a tension but an empirical question.

\section{How Does Heteronormativity Influence Low Desire in Women Partnered with Men?}

There are a number of possible pathways for how heteronormativity might influence low desire in women partnered with men. We outline four hypotheses (Fig. 1) for these pathways that are compelling, built on existing literature, and within our areas of expertise: inequitable gendered divisions of household labor, having to be a partner's mother, the objectification of women, and gender norms surrounding sexual initiation. These hypotheses, and the predictions we derive from them, are specific, testable, and falsifiable, and rooted in empirical reality, unlike the zombie facts that characterize much of the extant research. As such, we aim to show how low desire in women partnered with men may not be a problem itself and, instead, reflects one-namely, heteronormativity. Of note, our hypotheses are not meant to be an exhaustive list of all possible pathways; there may also be other, equally important and probable ways through which heteronormativity influences low desire in women partnered with men not listed below.

\section{Heteronormativity Hypothesis 1: Inequitable Gendered Divisions of Labor Leads to Inequitable Gendered Divisions of Desire}

In Prediction 1.1, women's higher number of labor hours, across labor type, contributes to their lower sexual desire. Heteronormativity brings about inequitable gendered divisions of labor for women partnered with men, cogently labeled a "second shift" by Hochschild and Machung (1989) over 30 years ago but as prevalent as ever. However, gendered divisions in some domains - like the workplace-are far outstripped by others-like personal lives (Coltrane, 2000, 2004; Hochschild \& Machung, 1989; Sayer, 2005). This is true for bedrocks of heteronormative assumptions about women's and men's essences: household labor, relational labor, and childcare. Women are therefore expected to - and do - the majority of inside-house work including relational labor (e.g., developing social plans, relationship maintenance, family management for children/ elders) (Curran et al., 2015; Erickson, 2005; Horne \& Johnson, 2019; Robertson et al., 2019).

In Prediction 1.2, inequities in the type of chores allotted to women contribute to their lower desire. Research has shown that women tend to do more of the routine and frequent chores such as cooking, washing dishes, cleaning, and laundry; these chores are sometimes called "low schedule control" chores because there is little discretion as to whether, how, and when they must be done (Barnett \& Shen, 1997; Estes et al., 2007). Men, on the other hand, tend to be in charge of more "high schedule control" chores such as home, car, and lawn maintenance, which are performed less frequently and with more flexibility. Absolute time spent on low, but not high, control chores is associated with increased psychological distress (Barnett \& Shen, 1997); thus, the inequitable allocation of low schedule control chores may also contribute to women's low sexual desire.

The psychological distress associated with low schedule control chores is part of what makes them unpleasant. There 
are also other inequities in the pleasantness of the chores allocated to women. For example, research has shown that there is an inequitable division in the "recreation-style" aspects of childcare like playing games or reading (which make up a greater portion of men's parenting) and "chore-like" aspects like diapering or feeding (which make up a greater portion of women's parenting) (Craig \& Powell, 2011). Of course, some of these "chores" can be enjoyable and involve loving and caring, but much of the labor that disparately falls on women is widely acknowledged to be unpleasant (Coltrane, 2000), including cleaning urine, feces, and toilets for children, elders, and others who need it. ${ }^{6}$ Research is clear that men try and do avoid these kinds of chores (Bianchi et al., 2012; Craig \& Powell, 2011), even in the face of women partners' attempts to move to parity (Latshaw, 2015; Lockman, 2019). It is not difficult to imagine who disproportionately benefits from structures built around the belief that women "naturally" want a similar amount of paid work hours to men's but also additional unpaid shifts at home performing unpleasant and mundane chores with less time for recreation and relaxation.

In Prediction 1.3, gender inequities in childcare more broadly contribute to women's lower sexual desire. Childcare patterns are starkly bifurcated, with women performing $~ 70 \%$ in heterosexual/mixed-gender/sex couples (and heightened during the COVID-19 epidemic; Fodor et al., 2020). Given these inequities in parenting, women who are parents may feel more like a mother than a partner (Sims \& Meana, 2010), and our culture desexualizes parenting and mothers in particular (Friedman et al., 1998). Of course, women might actually report finding some parenting chores more rewarding and be reluctant to give them up - but feelings can and do reflect internalized social norms and learned skills. For example, women who choose not to do this parenting labor are often penalized and are held to standards whether chosen or not (Cuddy et al., 2004; Dunn et al., 2013; Hays, 1996; Prentice \& Carranza, 2002). And, of course, parenting labor can be rewarding, as most any kind of labor can, and is clearly valuable and important. The assumption that feminine-typed labor is inherently bad or worse is a mainstay of both sexism and femmephobia (Hoskin, 2017; Levant \& Richmond, 2008). But it is undervalued and un/derpaid, seen as unimportant and beneath masculinity, and is prescribed for women whether they find it meaningful or not.

In Prediction 1.4, gender inequities in recreation, leisure, and relaxation also contribute to women's lower desire. Time spent in labor is time not spent relaxing, and men's amount of hours in relaxation and/or recreation far outstrips that of women (Bianchi et al., 2012; Shaw, 1985; Thrane, 2000).

\footnotetext{
${ }^{6}$ We note that it is possible that more exposure to unpleasant chores could actually lessen disgust to a range of bodily scents and fluids in ways that might even be helpful to women's desire.
}

Predictions 1.1-1.4 may reflect total hours women spend or hours women spend relative to partners. And, they may be moderated by women's perceptions of this as inequitable and/ or unfair.

In Prediction 1.5, gender inequities in standards for household labor contribute to women's lower desire. The ways these inequities in labor are managed (or not) could also impact desire. Many women report frustration at men partners' unwillingness or inability to do tasks required for maintaining a household or family in general, but also to the standards women are held to and socialized to prioritize (Hooff, 2011; Thompson \& Walker, 1989). Of course, since housework is perceived to be women's work, men have no reason to expect cultural judgements for failing to meet the same (high) standard women are held to (Harrell, 1995; Thébaud et al., 2019). Yet these standards are not arbitrary; women's standards are objectively reasonable for addressing hygiene, relational maintenance, family cohesion, and so on, but often treated as if they were arbitrary and extreme (Lockman, 2019; Thompson \& Walker, 1989; Hochschild \& Machung, 1989). This prediction (1.5) may be moderated by women's perceptions of the situation as inequitable and unfair, or by arguments about quality standards.

In Prediction 1.6, women's recognition of gender inequities in labor contributes to their lower desire. Recognizing, navigating, or preventing inequities is another (inequitable) form of labor. Those who benefit from inequities rarely recognize them unprompted. ${ }^{7}$ Instead, those who bear the brunt are the ones to recognize, address, and work toward change (Duncan, 1999; Haraway, 1988), which is a key insight of feminist standpoint theory (Ferree, 1990; Harding, 1986, 2004; Pleasants, 2011). Recognizing inequities is, itself, a form of labor we might call "inequity labor." It might lead women to question the disconnect between their planned selves, situations, or relational roles, and feel disappointment or frustration at the answers (Hochschild \& Machung, 1989). Feminist identity may support this process because it helps to make sense of inequities in a structural sense but it could also lead to a deeper recognition of existing inequities and the distance between the partner they were led to expect and the one they have (Yoder et al., 2007). This prediction may be moderated by the magnitude of the inequity, if more inequity leads to more frustration, or not, because inequities are violations regardless of their size.

In Prediction 1.7, the inequity in women's labor to redress inequitable distributions of labor can contribute to their lower desire. Recognition is not the end of inequity labor; once recognized, inequities can only be changed when someone makes the effort to challenge or redress them, and this can be met

\footnotetext{
${ }_{7}$ One of us knew a couple where the woman thought she was taking turns with her partner cleaning the toilet-and the man thought they had a self-cleaning toilet. She was the one who eventually realized and mentioned this.
} 
with resistance or resentment (Lockman, 2019). Women often have to ask men to equitably share household, relational, and childcare labor — commonly called "nagging" (Hochschild \& Machung, 1989; Latshaw, 2015; Thompson \& Walker, 1989). Nagging is rarely recognized as an attempt to mitigate gender inequities in labor, but it is clearly another kind of inequity labor. This prediction may be moderated by outcome and whether women recognize their efforts as addressing gendered inequities or not. Moreover, impacts of inequity labor might be exacerbated for marginalized women who have even less power, motivation, and/or ability to address labor inequities than majority women. These might include, for example: low/ no income women who rely more heavily on men partners for housing or financial stability; Black, Latino, and Indigenous women because of racist carceral policies that imprison high numbers of Black, Latina, and Indigenous men, reducing available partners (Gottschalk, 2008; Lopez-Aguado, 2016; Wakefield \& Wildeman, 2011), and women of color more generally because of beauty standards that reflect racist, colonialist, and anti-Black/misogynoir standards (Bailey, 2010; Jerald et al., 2017; Trudy, 2014; Ward et al., 2020).

In Prediction 1.8, relationships with equitable divisions of labor will have less pronounced or absent gender/sex differences in partners' desire. Images of men doing chores that are amusingly called "porn for women" (Cambridge Women's Pornography Cooperative \& Anderson, 2007) make a more serious point than often granted. They are not just a representation of a man doing a household chore, but a man doing a chore that many women's partners refuse to do-at all or without prompt or resentment. When men partners equitably share what would otherwise be an outsized chore list, this could free up time, decrease stress, and increase closeness and trust in ways that are beneficial to sexuality. In a study titled "Why did passion wane?", a number of women identified their extensive to-do lists as a cause of their low desire (Sims \& Meana, 2010). One woman stated: "Sex is just... not the priority right now. I would rather make sure the bills are paid, clean the house, I'd rather do things that need to get done" (Sims \& Meana, 2010, p. 373). It is not surprising that the inequitable divisions of labor would translate into inequitable divisions of desire.

\section{Heteronormativity Hypothesis 2: Having to be a Partner's Mother Dampens Women's Sexual Desire}

In Prediction 2.1, heteronormativity's inequitable casting of women into a caregiver-mother role to men partners contributes to the women's lower desire. While heteronormativity slots women into nurturant caregiving roles in general, this caregiving is also directed at men partners specifically (Duncombe \& Marsden, 1993). Nurturance-warm, loving, and caring treatment-is a critical aspect of long-term and/or successful relationships, but one inequitably shared between women and men in relationships with each other (Erickson, 1993; Hammond \& Overall, 2015; Thompson \& Walker, 1989). Heteronormative asymmetries in caregiving can matter not only because they are inequitable, but because they translate into dependencies that contravene contemporary norms of relational interdependence.

Interdependent relationships involve a mutual ethic of care, with partners supporting each other simultaneously or sequentially, akin to a something like a mix of equals, friends, and sexual partners (Aron \& Aron, 1986; Blumstein \& Schwartz, 1983; Schwartz, 1995; Waite \& Gallagher, 2001). The gender inequities inherent to heteronormative framings of complementarity violate norms of relational interdependence, transforming expectations of a partner-partner relationship into something closer to one that is caregiver-dependent or mother-child. Women end up doing many of the same things for their men partners as mothers do for their children, e.g., reminding them of chores, organizing social events (or playdates), buying clothes, ensuring there is food for snacks and meals and that these are made available (Lockman, 2019). Additionally, women often take on tasks for their husbands or other men partners that were originally performed by the men's mothers, perhaps an implicitly-held leftover from more historical understandings of marriage (Hochschild \& Machung, 1989; Hooff, 2011; Walters \& Whitehouse, 2012).

To be clear, there is nothing inherently unsexual about caregiving or dependency, and we are not valorizing independence. And, partner-directed caregiving can reflect situations of need that will arise for most people at some point (e.g., health, aging, disability, pregnancy, postpartum, phase of life, extended family demands). ${ }^{8}$ Additionally, there is nothing inherently unsexual about mothering; but the relationship between mothers and those they mother is not a sexual one. ${ }^{9}$ Mothering is a role that necessitates caregiving (children cannot look after themselves) and can be chosen. However, men partners can look after themselves, and the role of caregiver of a partner is typically taken on as a result of social norms rather than an active decision about caregiving. As such, associations between an inequitable casting of women into a caregiver-mother role to men partners and sexual desire may be moderated by whether women choose this role without constraint (which would make it a negotiated role, rather than a mandated one) or not (if this role is inimical to desire).

\footnotetext{
8 Though even need-based partner dependencies can be mired in gender inequities; for example, men may be less likely than women to act as a caregiver than hire one (de Ruijter et al., 2005).

${ }^{9}$ Some mothers and others talk about the sensuousness of touch with infants (Riordan \& Rapp, 1980); this aspect of mothering does not reflect the majority of mothering labor and few describe it as sexual (because sensuousness can be sexual but is not necessarily so). In a separate point, some people engage in caregiving sex play that they specifically choose (Kyrölä, 2011), which differs from our discussion; it involves agency, choice, and conscious sexualization.
} 
In Prediction 2.2, the increase in nurturant inequities over the course of relationships contributes to women's decreasing desire over relationships. This stands in contrast to the typical attributions for women's decreased desire over relationships (Murray \& Milhausen, 2012), which tend to focus on decreases in passion or testosterone that are presumed to come with age (Kingsberg, 2002; Levine, 2003; Vohs \& Baumeister, 2004). There may be numerous pathways. It may be additive or compounding, as inequities build over time and/or are exacerbated by their history. It may reflect increase in the caregiver-mother role over time. It may become more salient when set against other caregiver roles that arise over time (e.g., parenting, elder care), because of the insights resulting from the juxtaposition of need-based dependencies against non-need-based dependencies of men partners. Finally, it may be heightened by major life changes or situations (e.g., a move, a holiday) that asymmetrically add to the mother-caregiver role.

Of course, as we noted earlier, desire is multifaceted and can be targeted (Chadwick et al., 2017b). So, in Prediction 2.3, the mother-caregiver effect may contribute specifically to women's lower partner-targeted desire.

\section{Heteronormativity Hypothesis 3: Objectification of Women Downregulates Women's Desire}

In Prediction 3.1, the heteronormative push for women to focus on their appearance, especially during and in reference to sexual activity, contributes to their low desire. Heteronormativity focuses on women's sexual appearance over their pleasure, socializing women to be sexy rather than sexual (de Beauvoir, 1952; Fredrickson \& Roberts, 1997; Wiederman, 2000, 2005). It positions women as sexual objects for men partners, and women's bodies as offerings gifted to men for sex as part of a relationship contract (Bartky, 1990; Fredrickson \& Roberts, 1997). This can result in sexual objectification (Drolet \& Drolet, 2019; Durham, 2007; Frederickson \& Roberts, 1997; Ward, 2016). The internalization of this objectification - sexual selfobjectification (Frederickson \& Roberts, 1997) — means that women's desire is often contingent upon whether they think they are desirable.

Internalized sexual self-objectification-in conjunction with neoliberalism — can mean that women spend a great deal of energy preparing their bodies for, and focusing on their appearance during, sex (Bartky, 1990; Frith, 2015; Wolf, 1990). As heteronormative beauty norms are largely unattainable (Thompson et al., 1999), focusing on them actually means focusing on failing to meet beauty norms. Women report high levels of body dissatisfaction at clinical and "sub-clinical" levels, including disordered eating and eating disorders (Croll et al., 2002; Hoek \& Hoeken, 2003; Solmi et al., 2014). And, research has shown that, among women, greater self-objectification and dissatisfaction with one's body is associated with worse sexual experiences, including lower sexual self-esteem, lower sexual satisfaction, and lower sexual pleasure (Woertman \& Brink, 2012).

This body dissatisfaction also relates specifically to women's genitals. People are taught that vaginas and vulvas are dirty and unhygienic, hence the prevalence of so many cleansing regimens and products (Braun \& Wilkinson, 2005; Fahs, 2014b; Jenkins et al., 2018; Moran \& Lee, 2016). This messaging can make men partners reluctant to perform, and women less likely to ask for, cunnilingus (Backstrom et al., 2012; Reinholtz \& Muehlenhard, 1995; Roberts et al., 1996). Not surprisingly, women report feeling distracted by their concerns about their genitals in general and during sex (Schick et al., 2010). This judgement and self-monitoring could distract from sexual enjoyment and pleasure, and be at cross-purposes with experiencing desire (Cherkasskaya \& Rosario, 2017). Thus, low desire may reflect absolute levels of self-monitoring or these relative to levels of sexual pleasure. And, this association may be moderated by the accompanying worry, scrutiny, or cognitive distraction (Meana \& Nunnink, 2006; Wiederman, 2000) or being unable to engage in pleasurable sexual activities.

Of course, not all pleasure in appearance is objectifying. Some women enjoy or take pride in their appearance in ways that reclaim their bodies from those who would desexualize or pathologize them. This changes a focus on appearance from a source of anxious scrutiny to one of power and pleasure, as with fat women learning to take pleasure in their fatness in a fatphobic world, or masculine-of-center women taking pleasure in related clothing in a heteronormative world (Gailey, 2012; Rand, 2017). Accordingly, Prediction 3.1 may be moderated by pride/reclamation.

In Prediction 3.2, women's proximity to heteronormative beauty norms matters for their sexual desire. While heteronormative beauty norms are generally unattainable, there are still women who are positioned closer or further away from them. Closer proximity could actually contribute to higher desire in women, because there is less distance between ideal and actual appearance, appearance is seen as more cause for celebration than censure, and because women are taught to value being sexy over being sexual (Jeffreys, 2014; Mears, 2014). Or, proximity could contribute to lower desire because it inheres more focus on appearance: more comments about it, more internalization of its importance, more appearance labor, more value placed on labor, and more salience of the gap between ideal and actual that just might be closed with that much more effort.

In Prediction 3.3, socioeconomic status (SES) matters in specific ways for the links between women's focus on their appearance and their desire. Effort is deeply implicated in heteronormative foci on appearance and neoliberal imperatives hold that beauty standards might just be attainable with enough effort and expense (Blum, 2003; Gill, 2007, 2008). As such, for privileged women, SES might be positively linked with sexual desire because more financial resources allow women to get closer to beauty standards. But, these greater resources might 
translate into even more effort, and all that entails, meaning lower desire. Effects might be more complex for low-income, poor, and working class women, who are painted as crudely sexual and "over"-reproducers (Lennon, 2019; Szymanski et al., 2010), yet told that the only way out of poverty might be their appearance leading to marriage, especially with a high SES man.

In Prediction 3.4, feminist identity influences the links between women's focus on their appearance and their desire. Feminist women do report more positive sexual parameters (Bay-Cheng \& Zucker, 2007; Schick et al., 2008), which may reflect that feminism encourages women to step outside the heteronormative valuing of appearance over pleasure. Yet, there may be a curvilinear association between feminist consciousness and sexual desire, since feminism inheres recognition of gender inequities. This may make beauty ideals more obvious but, without redress, more disconcerting (Fischer \& Good, 2004). Indeed, "stepping outside" heteronormative beauty ideals may be particularly difficult for women partnered with men, since this relational formation largely (though, of course, not always) exists squarely within heteronorms.

In Prediction 3.5, ignorance about the vulva and clitoris negatively impacts desire in women partnered with men. Sex education tends to push heteronormative objectification, focusing on vaginas as "birth canals," often omitting clitorises (Bennett, 1993; Braun \& Kitzinger, 2001; Ogletree \& Ginsburg, 2000; Waskul et al., 2007), and near-universally ignoring their arousal-induced erectile and vasocongestive properties. Sex education often is missing "discourses of desire" (Fine, 1988), specifically for women and/or people with vulvas. It tends to focus on penis-vagina sex, which many women enjoy, but fewer find consistently orgasmic and/or highly pleasurable (Blair et al., 2018; Fahs, 2014c; Herbenick et al., 2018; Lloyd, 2009). Many have made the point that the ignorance surrounding vulvas and women's sexual pleasure basically mandates lower sexual pleasure and desire in women (Fahs \& Plante, 2017; Hayfield \& Clarke, 2012; Herbenick, 2009; McClelland, 2010; Mead, 1973).

In Prediction 3.6, the focus on men's sexual pleasure at the expense or erasure of women's pleasure negatively impacts the women's sexual desire. The heteronormative framing of women as sex objects can portray sex as something men do to women. It is not surprising, then, that women are subject to higher rates of sexual abuse and assault (Muehlenhard et al., 2017). Even within consensual sex, sexual scripts increasingly, and disproportionately, involve women on the receiving end of rough sex behaviors such as choking, slapping, and aggressive fellatio (Herbenick et al., 2019, 2021; Sun et al., 2008) (which some experience as pleasurable but many or most do not) as well as sex that moves beyond unpleasurable and into frightening territory (Herbenick et al., 2019). Even when women's pleasure is on the table, it can be in the service of men: some men see women's orgasms as trophies signaling the men's sexual ability rather than experiences of the women's pleasure (Chadwick \& van Anders, 2017; Salisbury \& Fisher, 2014).

\section{Heteronormativity Hypothesis 4: Gender Norms Surrounding Sexual Initiation Contribute to Women's Low Sexual Desire}

In Prediction 4.1, women's discomfort initiating sex will be associated with their lower desire. Sex between women and men happens more often when men want sex compared to when women want it (Herbenick, 2019); this is often attributed to lower desire in women despite evidence to the contrary (Mark, 2014; Mark \& Murray, 2012; Murray, 2019). As a mainstay of heteronormativity, women are taught to be responsive to men's sexual initiation but not to be agentic about starting sex, to avoid being labeled "frigid" or a "slut" (Armstrong et al., 2014). Not wanting sex when a partner initiates is not the same as not wanting sex. It may also be that men partners' comfort with women initiating sex will positively contribute to the women's desire.

In Prediction 4.2, women's discomfort with experiencing sexual pleasure outside of penetrative sexual activity with men partners may contribute to the women's lower desire. Women's sexual pleasure within heteronormative framings is fraught. For example, women partnered with men report feeling like masturbating would be cheating on their partners (Fine, 1988; Goldey et al., 2016; Kaestle \& Allen, 2011) and therefore do not masturbate despite wanting to. Penetrative intercourse is painted as the only version of "real sex" within heteronormativity, but women have a low likelihood of experiencing orgasm (a highly pleasurable experience) with penetrative intercourse (Herbenick et al., 2018). Heteronormativity means that, though women may want to be sexual, even with men partners, they are often taught that they can't be in the ways that are more likely to feel pleasurable for them (Frith, 2015; Gill, 2009). This ongoing separation between experiences of desire and sexual pleasure may dampen desire because it is not reinforced or followed up by sexual activity that actually leads to sexual pleasure.

In Prediction 4.3, seeing sex as a duty to perform with men will contribute to lower desire in women. Some women have sex they want, and some women have sex that their men partners want and that the women are open to. But a number of women (and almost no men) have reported in a nationally representative survey that they engaged with sex because it was part of their job, a duty or obligation of being married (Herbenick et al., 2019), which is a heteronormative hallmark. "Duty sex" is not very sexy, and people-including men-report losing sexual interest in this situation (Loewenstein et al., 2015; Pepe \& Byrne, 1991), as occurred in our case study above.

In Prediction 4.4, women's inability to refuse sex-with a man partner and/or within culturally-induced perceptionsmay contribute to their lower desire. Sex might be a "job requirement" for women partnered with men, and one that some 
women cannot refuse because of their lower social power. The only recent illegality of "marital rape" highlights this (Russell, 1990). While many experience taking on a low power position as sexy when consensually chosen, it is otherwise an undesirable and troubled position forced upon people. Women may be unable to refuse sex because of justified fears of violence or resource withdrawal, which might be exacerbated by differences in income (Amaro \& Raj, 2000; Kalichman et al., 1998). They may feel unable to refuse because of less severe but still significant outcomes, like men becoming emotionally demanding or withdrawn, and coercive (Katz \& Tirone, 2010; Willis $\&$ Nelson-Gray, 2020). And, even with respectful partners, the larger landscape of sexual violence, harassment, abuse, and assault that women experience (Fahs, 2014a; Finkelhor et al., 1990; Pain, 1991; Tjaden \& Thoennes, 2000) can make for a coupling between sexuality and fear (Vance, 1984). This tie between unchosen feelings of low power and vulnerability could make it harder to feel desire for a man, even trusted and loved ones.

\section{Physiological Mechanisms for the Heteronormativity Theory of Low Desire in Women Partnered with Men}

Heteronormativity could impact sexual desire in women partnered with men via pathways we have hypothesized (Fig. 1) and more. Obviously, testing the theory and its hypothesized predictions could occur via a number of disciplines, mechanisms, and approaches that we discussed above. In this section, we focus on two potential physiological mechanisms for pathways: stress (and cortisol) and nurturance (and testosterone). We focus on these two based on our own areas of expertise.

So far, we have largely criticized approaches to low sexual desire in women that focus on biomedical causes and fixes. Accordingly, attention to hormones might seem counterintuitive at best. But, critiques of biologism are not the same as critiques of biology. Much of the biological research on human sexuality is biologically essentialist, determinist, and reductionist (Fausto-Sterling, 2000; Tiefer, 2004), yet these biologisms are not inherently part of biological research, and it is possible to do research with biology outside these framings (Hyde et al., 2019; van Anders, 2013). One of these approaches includes social neuroendocrinology (van Anders \& Watson, 2006; van Anders et al., 2011), which explores interactions between hormones and social behavioral contexts. It is a useful approach for exploring how heteronormativity might impact low desire in women partnered with men, and situates biological aspects of low sexual desire as partly the function of social factors that shape human bodies.

\section{Heteronormativity's Impacts on Stress}

Stress refers to perturbation of homeostasis or changes to one's regular bodily state (Karatsoreos \& McEwen, 2011; Lee et al., 2015). Stress is typically presumed to be negative or unwanted because of its colloquial usage, but the term refers to a valueneutral process whereby bodies respond to changes in the internal or external environment. As a result, stress can result from negative situations, like anticipating genital pain with sexual activity, and positive ones, like wanted sexual arousal (Pacik, 2014; Payne et al., 2006). Stress can also vary by duration, with short-term (acute) or long-term (chronic) stress.

Chronic stress has adverse effects on sexuality, especially for women (Hamilton \& Meston, 2013). There are a number of ways it might impact sexual desire. One might be through cognitive distractions: stress might reflect or lead to a reallotment of cognitive energy toward worries rather than sexuality, or stress might temporarily decrease the sexual saliency of otherwise sexual stimuli. Another might be via hormones like cortisol, a hormone linked to stress that is released from the adrenal gland in response to a cascade of hormonal triggers.

Stressful experiences can lead to cortisol release and this includes positive "stressors." For example, sexual arousal-an acute stressor, though usually a wanted and enjoyable one-is associated with increases in cortisol (Loving et al., 2009). But, chronic stress can overstimulate the adrenal glands, leading to chronically high levels of cortisol and-perhaps counterintuitively-hypoactive adrenal glands that no longer respond to individual stressors. Accordingly, chronically high stress and its concomitantly high cortisol can, in turn, prevent or dampen acute stress responses, including sexual arousal (Bunea et al., 2017; Lam et al., 2019; Miller et al., 2007; Tomiyama et al., 2011). Similarly, chronic stress can even impact whether cues are perceived as sexual and whether sexual stimuli are perceived as the hedonic — or pleasureful—stimuli they might otherwise be (ter Kuile et al., 2007). Since arousal and desire can be mutually reinforcing (Basson et al., 2005; Goldey \& van Anders, 2012), the absence of arousal could negatively impact desire. After all, why desire sexual activity when there is little or nothing to be aroused by?

Stress is a general physiological mechanism that people of all gender/sexes experience, but is inequitably distributed by gender-women report higher stress and more stress-related health issues than men do (Bodenmann et al., 2006; Mayor, 2015; Morokoff \& Gillilland, 1993). As such, we propose that stress is a plausible pathway for many effects of heteronormativity on low desire in women partnered with men, especially given that many of the norms and pressures outlined in our 
hypotheses tend to be associated with higher stress levels. For example, research has shown that more hours of household and childcare labor and less time for relaxation or recuperation contributes to increased stress in women (Coltrane, 2000). Additionally, pregnancy as well as babies/children can disrupt sleep, sometimes indefinitely, and mothers sleep less than fathers (Gay et al., 2004). Sleep deprivation itself has been directly linked with depression, mood disturbances, and alterations in cortisol rhythms over the day (Armstrong et al., 1998; MontgomeryDowns et al., 2013; Wright et al., 2015). Furthermore, research has suggested that the physical demands of some labor, like childcare and eldercare, could in themselves lead to stressful health challenges. Many women report chronic back and neck pain (Côté et al., 2004; Guez et al., 2002; Hogg-Johnson et al., 2008; Meucci et al., 2015)—which may stem from breastfeedingand chestfeeding, carrying, rocking, lifting, and even inadequate healthcare for postpartum abdominal changes (Altinel et al., 2008; Meucci et al., 2015). Moreover, sexual coercion and abuse, as well as sexually transmitted infections and unwanted pregnancies (actual or potential), always offer the possibility for distress, stigma, and trauma, a fact of life that scholars have argued creates an ever-looming sense of anxiety in women's sexual lives more broadly (Vance, 1984). On top of this, heteronormativity discourages women from attending to even basic needs, including those that might aid health or ease pain (Grant et al., 2017; Hays, 1996), which may compound the stressful effects of women's roles and labor even more. As such, it perhaps makes sense that the chronic stress of women's heteronormative roles could be responsible for low desire-for example, because this chronic stress could blunt the acute cortisol responses that would more typically accompany sexual stimuli in ways that contribute to low desire. Supporting this notion more broadly, issues with sleep, physical health and well-being, and mental health, are highly correlated with sexual difficulties (Basson et al., 2005; Kalmbach et al., 2015), and indeed many women report they are simply too fatigued to experience desire (Sims \& Meana, 2010).

Moreover, that low desire is seen as a medical and health issue could make for a circular association between it and chronic stress. Women come to know their desire as "too low" and report feeling like failures as women and partners (DeRogatis et al., 2008), making for an iatrogenic source of chronic stress. Locating the "problem" of low desire in women's bodies and minds ultimately places the responsibility for it on women, arguably a form of gaslighting when the problem exists outside women and will not be fixed with individual effort. This can exacerbate women's stress, by placing yet another responsibility on their shoulders but one that is impossible: to fix their desire problem by fixing themselves, when they are not the problem.

The focus on low sexual desire can be stressful and cognitively distracting, as women look for fixes that cannot exist. This form of "sexual labor" often extends beyond women who are actively concerned about their low desire to women more generally. For example, women are assumed to be responsible for keeping a couple's sexual life sexy, in part because their sexuality (i.e., desire, arousal, and orgasm) is seen as more complicated and "difficult" than men's (Jackson \& Scott, 2002; Meana, 2010). ${ }^{10}$ Most sex self-help books are targeted to women readers and sex tips in women's magazines tend to focus on how to turn their male partners on (or otherwise "wow" him) rather than how to enhance their own sexual pleasure or explore their own personal fantasies (Cacchioni, 2007; Gill, 2009). While men are more often expected to purchase and carry condoms (Petersen \& Hyde, 2010), condom use is generally short-lived within dyads and transitions to longer-term contraceptives, which are more often seen as women's responsibility over decades (Fennell, 2011; Fortenberry et al., 2002). Additionally, women are taught that vaginas and vulvas are dirty and unhygienic, and that pubic hair is messy, which puts pressure on women to make sure that their bodies are devoid of all "bad" smells, fluids, sights, "extraneous" hair(s), and sounds (e.g., body odor, sweat, menstrual blood, pubic hair, "queefing") during sex (Braun \& Kitzinger, 2001; Butler et al., 2015, p. 201; Fudge \& Byers, 2017). Simultaneously, women are supposed to work to ensure that they also have and/or perform all of the "good" smells, fluids, sights and sounds (e.g., via perfumes, douching, vaginal lubrication, sexy/sexualized clothing, moaning) (Cacchioni, 2007; Fahs, 2014b; Leiblum, 2001; Loe, 1999; Reece et al., 2004) and that they have a range of sex toys and lubricants/cream to make sex exciting (McCaughey \& French, 2001). This can be a heavy cognitive load and list of things to worry about before and during sex; and cognitive distractions are known to complicate sexual arousal (Adams et al., 1985; Carvalho \& Nobre, 2010; Dove \& Wiederman, 2000). As such, it perhaps makes sense that women's long list of things to worry about may contribute to chronic stress, interfere with arousal-induced acute stress responses that are part of most sexual processes, or prevent women from experiencing sexual stimuli as sexual (after all, if "sexual" stimuli really cue sexual "labor," they may be tied more to "labor" than to "sexuality").

Heteronormativity's Impacts on Nurturance Heteronormativity streams women into caregiving roles, for children, elders, and others. One implication of this nurturant streaming is neurobiological. Building off of a broad literature on social bonds and hormones (Carter, 1998; Diamond, 2003; Fernandez-Duque et al., 2009; Fisher, 1992), the "steroid/peptide theory of social bonds" (S/P Theory) describes a nurturant system in humans and other species that evolved to promote care of offspring

\footnotetext{
10 Though research has shown no gender/sex differences in time to orgasm from masturbation (Paterson, Jin, Amsel, \& Binik, 2014). This fact alone should be enough to convince any critical thinker that the difficulty women experience in arousal or orgasm with men partners cannot be located in the women's bodies but in their sexual relations with men or the men themselves; that it is not is telling.
} 
and children (van Anders et al., 2011). This species-specific "nurturant system" works in two ways: nurturant experiences decrease testosterone, and increase peptides like oxytocin and vasopressin. But the rub is: these hormones are themselves implicated in sexual responses and desire. For example, testosterone is linked with desire-in nuanced, complex, and mediated ways that are far from the caricature of direct linear effects (Raisanen et al., 2018; van Anders, 2012, 2013; van Anders et al., 2007a, 2007b). Accordingly, nurturant roles for women might, over time and/or acutely, actually decrease testosterone (van Anders et al., 2015), with concomitant feedforward decreases in sexual parameters. The nurturant aspect of heteronormative gender roles for women may thus be an important pathway to low desire via the upregulation of nurturant hormonal systems that involve decreases in some sexually-relevant hormones (though of course some sexuality has nurturant aspects, van Anders et al., 2011).

We have delineated how heteronormativity pushes women into nurturant roles that include caregiving for dependentswhich can include men partners. This, too, has neurobiological implications. In the S/P Theory, there is a second neurobiological system relevant to social bonds: an erotic-or "competitive"-system in humans and other species that evolved to promote reproduction (van Anders et al., 2011). In this species-specific "competitive system," erotic aspects of sexual experiences increase testosterone and peptides like oxytocin and vasopressin (van Anders et al., 2011, 2014). This competitive system and the nurturant system can work together in many situations; for example, long-term relationships clearly can and usually do involve nurturance and eroticism. Many aspects of sexuality inhere both aspects as well. But, while social bonds with dependents can involve nurturance, they do not involve eroticism. Indeed, caregiving in general seems to cue an upregulation of the nurturant system - and a downregulation of the eroticism (Gettler \& Oka, 2016; van Anders, 2012; van Anders et al., 2012, 2014). Accordingly, in the same ways that dependent children cue nurturance but not eroticism from mothers, men's dependence on inequitable nurturant labor from women partners might upregulate women's nurturant system and downregulate their competitive/erotic one. The mothercaregiver role that women find themselves cast in within heteronormative frameworks might cue this nurturant hormonal system, lowering desire and leading women to view dependent men's sexual overtures as inappropriate, non-erotic, or even disgustful.

Of course, sexual desire is not one thing; it can reflect desire for a host of experiences that include pleasure, stress relief, and other factors (Chadwick et al., 2017a). These can vary for solitary sexual desire or partnered sexual desire, since these overlap but also diverge (van Anders, 2012). Thus, it may be that certain aspects of women's sexual desire are especially affected by heteronormativity's push to nurturance. For example, this caregiver-mother role to men partners might have a selective dampening effect on partnered desire relative to solitary desire, or desire for pleasure or orgasm. It may dampen women's partnered desire only for the men partners but not for non-partner others like friends, strangers, or other fantasized individuals and may even increase non-partner desire. Accordingly, there may be specific effects on specific forms of desire, a re-targeting of the system, or even a general downregulation of the erotic system.

Hormones like testosterone and evolved neurobiological systems as with the S/P Theory might seem like unlikely pathways for exploring the impact of heteronormativity on low desire in women partnered with men. Indeed, heteronormativity is more often used as a critique of hormone research than a hypothesis for it. But social neuroendocrinology - the iterative and bidirectional study of hormones and social behavioral contexts-is rooted in feminist approaches and calls for attention to humanspecificities like social constructions, which include heteronormativity (van Anders, 2013; van Anders \& Watson, 2006; van Anders et al., 2011). In other words, it provides an important model of doing biology rather than biologism; and, it is a way to ask questions with biology that are not biologically essentialist, determinist, or reductionist (van Anders, 2014; van Anders \& Watson, 2006).

\section{Conclusions}

In this paper, we introduced the heteronormativity theory of low sexual desire in women partnered with men. We began by presenting the couple Denise and James, and how the contingencies of their lives were clearly causing Denise's low desire, which was not reflected in James' search for a "female Viagra" as treatment. We then briefly discussed desire, low desire, and asked whether low desire was a problem and, if so, why, for whom, and where. We introduced the concept of heteronormativity, and detailed how it could account for low sexual desire in women partnered with men. To do so, we presented four hypotheses and their related predictions, focusing on inequitable divisions of labor, the caregiver-mother role to men, a prescriptive focus on appearance, and norms about sexual initiation. In that discussion, we covered some possible mechanisms, including objectification. We then discussed physiological mechanisms focusing on two hormonal possibilities: stress and nurturance.

Throughout, we emphasized that there are additionalpotentially innumerable-hypotheses, predictions, methods, and pathways to bring to understanding low desire in women partnered with men. And, we highlighted that there is no natural reason to study this only in women partnered with men, but that we did so as a starting point related to where the "problem" of low desire is often situated in research and the larger public. We also discussed the ways that women partnered with men themselves are a heterogeneous group, and 
how most research - including this paper-that treats women as a singular group usually does so in ways that are conflated with majoritarian social locations (e.g., white, Western, middle class, able-bodied, heterosexual, "reproductively"-aged, cisgender, citizen, monoamorous, and beyond). We thus welcome and share passion toward understanding how the heteronormativity theory applies (or not) across gender/sex/ ualities and within specific groups of women, likely with social location-specific iterations.

Similarly, we did not provide or recommend a specific definition or method for operationalizing sexual desire, and instead embraced it as a vague concept (which we argue is actually similar to much research on sexual desire). One reason for this is because it is possible that heteronormativity might influence "desire" differently depending on how desire is conceptualized, and this empirical question in itself could expand our theory in new and meaningful ways. We welcome and encourage those interested in testing our theory to help us explore the aspects of sexual desire for which heteronormative theory is or is not relevant.

Heteronormativity matters for empirical approaches to low desire in women partnered with men, and clearly has already impacted the "scientific imaginary." Its focus on women as a natural, inferior, and complementary category to men has positioned low desire as a problem existing within women's bodies. It has thus shaped what questions and methods scientists are capable of asking, rewarded for pursuing, and encouraged to imagine. Heteronormativity is already in the science of low desire but in largely unquestioned ways; our theory instead foregrounds heteronormativity for a stronger explanatory framework (a process known as "strong objectivity," where bias is addressed rather than presumed either absent or cross-canceling as in traditional science; Harding, 1991).

We do not argue that heteronormativity is the only contributing factor to low desire in women partnered with men, or that social structures are the only thing shaping women's experiences of desire. Similarly, though we argue that low desire is not inherently a problem, we do not argue that it cannot be one. Yet, low sexual desire in women partnered with men has been treated as a problem or pathology located within women's bodies and reflecting biomedical or psychological causes that require individual treatment. The actual research on low desire in women partnered with men belies these assumptions, and shows how they are often without theoretical or empirical basis, and rarely reflect the testing or even exploring of alternatives. In contrast, the heteronormativity theory of low sexual desire in women partnered with men provides a scientific and scholarly approach that is theoretically grounded, testable, falsifiable, and rooted in an understanding of sexuality that is psychological, biological, relational, and structural — and, we argue, has the potential to transform the landscape of this research and sexual lives.
Acknowledgements This research was undertaken, in part, thanks to funding from the Canada 150 Research Chairs program to SMvA.

\section{Declarations}

Conflict of interest The authors declare that they have no conflict of interest.

\section{References}

Adams, A. E., Haynes, S. N., \& Brayer, M. A. (1985). Cognitive distraction in female sexual arousal. Psychophysiology, 22, 689-696. https:// doi.org/10.1111/j.1469-8986.1985.tb01669.x

Altinel, L., Kose, K. C., Ergan, V., Isik, C., Aksoy, Y., Ozdemir, A., Toprak, D., \& Dogan, N. (2008). The prevalence of low back pain and risk factors among adult population in Afyon region, Turkey. Acta Orthopaedica et Traumatologica Turcica, 42, 328-333.

Amaro, H., \& Raj, A. (2000). On the margin: Power and women's HIV risk reduction strategies. Sex Roles, 42, 723-749. https://doi.org/10. 1023/A:1007059708789

American Psychiatric Association. (2013). Diagnostic and statistical manual of mental disorders (5th ed.) American Psychiatric Press. https://doi.org/10.1176/appi.books.9780890425596

Cambridge Women's Pornography Cooperative, \& Anderson, S. (2007). Porn for women (Illustrated Edition). Chronicle Books.

Armstrong, E. A., Hamilton, L. T., Armstrong, E. M., \& Seeley, J. L. (2014). "Good girls": Gender, social class, and slut discourse on campus. Social Psychology Quarterly, 77, 100-122. https://doi.org/ 10.1177/0190272514521220

Armstrong, K. L., Van Haeringen, A. R., Dadds, M. R., \& Cash, R. (1998). Sleep deprivation or postnatal depression in later infancy: Separating the chicken from the egg. Journal of Paediatrics and Child Health, 34, 260-262. https://doi.org/10.1046/j.1440-1754.1998. 00213.x

Aron, A., \& Aron, E. N. (1986). Love and the expansion of self: Understanding attraction and satisfaction. Hemisphere Publishing Corp/ Harper \& Row Publishers.

Backstrom, L., Armstrong, E. A., \& Puentes, J. (2012). Women's negotiation of cunnilingus in college hookups and relationships. Journal of Sex Research, 49, 1-12. https://doi.org/10.1080/00224499.2011. 585523

Bailey, M. (2010, March 14). They aren't talking about me... Crunk Feminist Collective. http://www.crunkfeministcollective.com/2010/03/ 14/they-arent-talking-about-me/

Baker, J. (2012). Young women and housework. Australian Feminist Studies, 27, 339-354. https://doi.org/10.1080/08164649.2012.727268

Barnett, R. C., \& Shen, Y.-C. (1997). Gender, high- and low-schedulecontrol housework tasks, and psychological distress: A study of dual-earner couples. Journal of Family Issues, 18, 403-428. https:// doi.org/10.1177/019251397018004003

Bartky, S. L. (1990). Femininity and domination: Studies in the phenomenology of oppression. Routledge.

Basson, R. (2001a). Human sex-response cycles. Journal of Sex and Marital Therapy, 27, 33-43. https://doi.org/10.1080/0092623015 2035831

Basson, R. (2001b). Using a different model for female sexual response to address women's problematic low sexual desire. Journal of Sex and Marital Therapy, 27, 395-403. https://doi.org/10.1080/713846827

Basson, R. (2002a). Women's sexual desire: Disordered or misunderstood? Journal of Sex and Marital Therapy, 28, 17-28. https://doi.org/10. 1080/00926230252851168 
Basson, R. (2002b). A model of women's sexual arousal. Journal of Sex and Marital Therapy, 28, 1-10. https://doi.org/10.1080/0092623023 17250963

Basson, R., Brotto, L. A., Laan, E., Redmond, G., \& Utian, W. H. (2005). Assessment and management of women's sexual dysfunctions: Problematic desire and arousal. Journal of Sexual Medicine, 2, 291-300. https://doi.org/10.1111/j.1743-6109.2005.20346.x

Basson, R., Brotto, L. A., Petkau, A. J., \& Labrie, F. (2010). Role of androgens in women's sexual dysfunction. Menopause, 17, 962-971. https://doi.org/10.1097/gme.0b013e3181d59765

Baxter, J. (2005). To marry or not to marry: Marital status and the household division of labor. Journal of Family Issues, 26, 300-321. https://doi.org/10.1177/0192513X04270473

Baxter, J., Hewitt, B., \& Haynes, M. (2008). Life course transitions and housework: Marriage, parenthood, and time on housework. Journal of Marriage and Family, 70, 259-272. https://doi.org/10.1111/j. 1741-3737.2008.00479.x

Bay-Cheng, L. Y. (2015). The agency line: A neoliberal metric for appraising young women's sexuality. Sex Roles, 73, 279-291. https://doi. org/10.1007/s11199-015-0452-6

Bay-Cheng, L. Y., \& Zucker, A. N. (2007). Feminism between the sheets: Sexual attitudes among feminists, nonfeminists, and egalitarians. Psychology of Women Quarterly, 31, 157-163.

Bennett, P. (1993). Critical clitoridectomy: Female sexual imagery and feminist psychoanalytic theory. Signs: Journal of Women in Culture and Society, 18, 235-259. https://doi.org/10.1086/494792

Bettie, J. (2000). Women without class: Chicas, cholas, trash, and the presence/absence of class identity. Signs: Journal of Women in Culture and Society, 26, 1-35. https://doi.org/10.1086/495566

Bianchi, S. M., Sayer, L. C., Milkie, M. A., \& Robinson, J. P. (2012). Housework: Who did, does or will do it, and how much does it matter? Social Forces, 91, 55-63. https://doi.org/10.1093/sf/sos120

Blair, K. L., Cappell, J., \& Pukall, C. F. (2018). Not all orgasms were created equal: Differences in frequency and satisfaction of orgasm experiences by sexual activity in same-sex versus mixed-sex relationships. Journal of Sex Research, 55, 719-733. https://doi.org/10. 1080/00224499.2017.1303437

Blum, V. (2003). Flesh wounds: The culture of cosmetic surgery. University of California Press.

Blumstein, P., \& Schwartz, P. (1983). American couples. Morrow.

Bodenmann, G., Ledermann, T., Blattner, D., \& Galluzzo, C. (2006). Associations among everyday stress, critical life events, and sexual problems. Journal of Nervous and Mental Disease, 194, 494-501. https://doi.org/10.1097/01.nmd.0000228504.15569.b6

Braun, V., \& Kitzinger, C. (2001). "Snatch", "hole", or "honey-pot"? Semantic categories and the problem of nonspecificity in female genital slang. Journal of Sex Research, 38, 146-158. https://doi. org/10.1080/00224490109552082

Braun, V., \& Wilkinson, S. (2005). Vagina equals woman? On genitals and gendered identity. Women's Studies International Forum, 28, 509-522. https://doi.org/10.1016/j.wsif.2005.09.007

Brotto, L. A. (2010a). The DSM diagnostic criteria for hypoactive sexual desire disorder in women. Archives of Sexual Behavior, 39, 221-239. https://doi.org/10.1007/s10508-009-9543-1

Brotto, L. A. (2010b). The DSM diagnostic criteria for hypoactive sexual desire disorder in men. Journal of Sexual Medicine, 7, 2015-2030. https://doi.org/10.1111/j.1743-6109.2010.01860.x

Brotto, L. A., \& Basson, R. (2014). Group mindfulness-based therapy significantly improves sexual desire in women. Behaviour Research and Therapy, 57, 43-54. https://doi.org/10.1016/j.brat.2014.04.001

Brotto, L. A., Chivers, M. L., Millman, R. D., \& Albert, A. (2016). Mindfulness-based sex therapy improves genital-subjective arousal concordance in women with sexual desire/arousal difficulties. Archives of Sexual Behavior, 45, 1907-1921. https://doi.org/10. 1007/s10508-015-0689-8
Brotto, L. A., \& Yule, M. (2017). Asexuality: Sexual orientation, paraphilia, sexual dysfunction, or none of the above? Archives of Sexual Behavior, 46, 619-627. https://doi.org/10.1007/s10508-016-0802-7

Bunea, I. M., Szentágotai-Tătar, A., \& Miu, A. C. (2017). Early-life adversity and cortisol response to social stress: A meta-analysis. Translational Psychiatry, 7, 1-8. https://doi.org/10.1038/ s41398-017-0032-3

Butler, J. (1996). Imitation and gender insubordination. In A. Garry \& M. Pearsall (Eds.), Women, knowledge, and reality: Explorations in feminist philosophy (pp. 307-320). Routledge.

Butler, J. (2011). Gender trouble: Feminism and the subversion of identity. Routledge.

Butler, S. M., Smith, N. K., Collazo, E., Caltabiano, L., \& Herbenick, D. (2015). Pubic hair preferences, reasons for removal, and associated genital symptoms: Comparisons between men and women. Journal of Sexual Medicine, 12, 48-58. https://doi.org/10.1111/jsm.12763

Cacchioni, T. (2007). Heterosexuality and "the labour of love": A contribution to recent debates on female sexual dysfunction. Sexualities, 10, 299-320. https://doi.org/10.1177/1363460707078320

Cappelletti, M., \& Wallen, K. (2016). Increasing women's sexual desire: The comparative effectiveness of estrogens and androgens. Hormones and Behavior, 78, 178-193. https://doi.org/10.1016/j.yhbeh. 2015.11.003

Carter, C. S. (1998). Neuroendocrine perspectives on social attachment and love. Psychoneuroendocrinology, 23, 779-818. https://doi.org/ 10.1016/S0306-4530(98)00055-9

Carvalho, J., \& Nobre, P. (2010). Predictors of women's sexual desire: The role of psychopathology, cognitive-emotional determinants, relationship dimensions, and medical factors. Journal of Sexual Medicine, 7, 928-937. https://doi.org/10.1111/j.1743-6109.2009.01568.x

Cerankowski, K. J., \& Milks, M. (2010). New orientations: A sexuality and its implications for theory and practice. Feminist Studies, 36, 650-664.

Chadwick, S. B., Burke, S. M., Goldey, K. L., Bell, S. N., \& van Anders, S. M. (2017a). Sexual desire in sexual minority and majority women and men: The multifaceted sexual desire questionnaire. Archives of Sexual Behavior, 46, 2465-2484. https://doi.org/10.1007/ s10508-016-0895-z

Chadwick, S. B., Burke, S. M., Goldey, K. L., \& van Anders, S. M. (2017b). Multifaceted sexual desire and hormonal associations: Accounting for social location, relationship status, and desire target. Archives of Sexual Behavior, 46, 2445-2463. https://doi.org/10. 1007/s10508-017-0959-8

Chadwick, S. B., \& van Anders, S. M. (2017). Do women's orgasms function as a masculinity achievement for men? Journal of Sex Research, 54, 1141-1152. https://doi.org/10.1080/00224499.2017.1283484

Chasin, C. D. (2013). Reconsidering asexuality and its radical potential. Feminist Studies, 39, 405-426.

Cherkasskaya, E., \& Rosario, M. (2017). A model of female sexual desire: Internalized working models of parent-child relationships and sexual body self-representations. Archives of Sexual Behavior, 46, 2429-2444. https://doi.org/10.1007/s10508-016-0899-8

Clare, E. (2015). Exile and pride: Disability, queerness, and liberation. Duke University Press.

Clayton, A. H., McGarvey, E. L., \& Clavet, G. J. (1997). The Changes in Sexual Functioning Questionnaire (CSFQ): Development, reliability, and validity. Psychopharmacology Bulletin, 33, 731-745. Retrieved from https://www.researchgate.net/profile/Anita_Clayt on/publication/13737215_The_Changes_in_Sexual_Functioning_Questionnaire_CSFQ_Development_reliability_and_valid ity/links/ 5462385d0cf2837efdaff37c.pdf

Coltrane, S. (2000). Research on household labor: Modeling and measuring the social embeddedness of routine family work. Journal of Marriage and Family, 62, 1208-1233. https://doi.org/10.1111/j. 1741-3737.2000.01208.x 
Coltrane, S. (2004). Elite careers and family commitment: It's (still) about gender. Annals of the American Academy of Political and Social Science, 596, 214-220. https://doi.org/10.1177/0002716204268776

Connell, R. W., \& Messerschmidt, J. W. (2005). Hegemonic masculinity: Rethinking the concept. Gender and Society, 19, 829-859. https:// doi.org/10.1177/0891243205278639

Cooke, L. P. (2006). "Doing" gender in context: Household bargaining and risk of divorce in Germany and the United States. American Journal of Sociology, 112, 442-472. https://doi.org/10.1086/506417

Côté, P., Cassidy, J. D., Carroll, L. J., \& Kristman, V. (2004). The annual incidence and course of neck pain in the general population: A population-based cohort study. Pain, 112, 267-273. https://doi.org/10. 1016/j.pain.2004.09.004

Craig, L., \& Powell, A. (2011). Non-standard work schedules, work-family balance and the gendered division of childcare. Work, Employment and Society, 25, 274-291. https://doi.org/10.1177/0950017011 398894

Crawford, M., \& Popp, D. (2003). Sexual double standards: A review and methodological critique of two decades of research. Journal of Sex Research, 40, 13-26. https://doi.org/10.1080/00224490309552163

Crenshaw, K. (1993). Mapping the margins: Intersectionality, identity politics, and violence against women of color. Stanford Law Review, 43, 1241-1299. https://doi.org/10.2307/1229039

Croll, J., Neumark-Sztainer, D., Story, M., \& Ireland, M. (2002). Prevalence and risk and protective factors related to disordered eating behaviors among adolescents: Relationship to gender and ethnicity. Journal of Adolescent Health, 31, 166-175. https://doi.org/10.1016/ S1054-139X(02)00368-3

Cuddy, A. J. C., Fiske, S. T., \& Glick, P. (2004). When professionals become mothers, warmth doesn't cut the ice. Journal of Social Issues, 60, 701-718. https://doi.org/10.1111/j.0022-4537.2004. 00381.x

Curran, M. A., McDaniel, B. T., Pollitt, A. M., \& Totenhagen, C. J. (2015). Gender, emotion work, and relationship quality: A daily diary study. Sex Roles, 73, 157-173. https://doi.org/10.1007/s11199-015-0495-8

Davies, S., Katz, J., \& Jackson, J. L. (1999). Sexual desire discrepancies: Effects on sexual and relationship satisfaction in heterosexual dating couples. Archives of Sexual Behavior, 28, 553-567. https://doi.org/ 10.1023/A:1018721417683

Davis, S. R. (2005). Circulating androgen levels and self-reported sexual function in women. Journal of the American Medical Association, 294, 91-96. https://doi.org/10.1001/jama.294.1.91

Davis, S. N., Greenstein, T. N., \& Gerteisen Marks, J. P. (2007). Effects of union type on division of household labor: Do cohabiting men really perform more housework? Journal of Family Issues, 28, 1246-1272. https://doi.org/10.1177/0192513X07300968

Dawson, S. J., \& Chivers, M. L. (2014). Gender differences and similarities in sexual desire. Current Sexual Health Reports, 6, 211-219. https:// doi.org/10.1007/s11930-014-0027-5

de Beauvoir, S. (1952). The second sex (H. M. Parshley, Trans.). Knopf.

de Ruijter, E., Treas, J. K., \& Cohen, P. N. (2005). Outsourcing the gender factory: Living arrangements and service expenditures on female and male tasks. Social Forces, 84, 305-322. https://doi.org/10.1353/ sof.2005.0124

Decker, J. S. (2015). The invisible orientation: An introduction to asexuality. Simon and Schuster.

DeLamater, J. D., \& Hyde, J. S. (1998). Essentialism vs. Social constructionism in the study of human sexuality. Journal of Sex Research, 35, 10-18. https://doi.org/10.1080/00224499809551913

DeRogatis, L. R., Allgood, A., Rosen, R. C., Leiblum, S., Zipfel, L., \& Guo, C. (2008). Development and evaluation of the Women's Sexual Interest Diagnostic Interview (WSID): A structured interview to diagnose hypoactive sexual desire disorder (HSDD) in standardized patients. Journal of Sexual Medicine, 5, 2827-2841. https://doi.org/ 10.1111/j.1743-6109.2008.01008.x
Diamond, L. M. (2003). What does sexual orientation orient? A biobehavioral model distinguishing romantic love and sexual desire. Psychological Review, 110, 173-192. https://doi.org/10.1037/0033-295X. 110.1.173

Dougherty, T. (2015). Yes means yes: Consent as communication. Philosophy and Public Affairs, 43, 224-253. https://doi.org/10.1111/ papa.12059

Dove, N., \& Wiederman, M. W. (2000). Cognitive distraction and women's sexual functioning. Journal of Sex and Marital Therapy, 26, 67-78. https://doi.org/10.1080/009262300278650

Drolet, C. E., \& Drolet, A. M. (2019). Self-objectification, system justifying beliefs, and the rise of labiaplasty. Social Justice Research, 32, 318-348. https://doi.org/10.1007/s11211-019-00326-8

Duckitt, J. H. (1994). The social psychology of prejudice. Greenwood Press.

Duncan, L. E. (1999). Motivation for collective action: Group consciousness as mediator of personality, life experiences, and women's rights activism. Political Psychology, 20, 611-635. https://doi.org/10. 1111/0162-895X.00159

Duncombe, J., \& Marsden, D. (1993). Love and intimacy: The gender division of emotion and 'emotion work': A neglected aspect of sociological discussion of heterosexual relationships. Sociology, 27, 221-241. https://doi.org/10.1177/0038038593027002003

Dunn, M. G., Rochlen, A. B., \& O'Brien, K. M. (2013). Employee, mother, and partner: An exploratory investigation of working women with stay-at-home fathers. Journal of Career Development, 40, 3-22. https://doi.org/10.1177/0894845311401744

Durham, M. G. (2007, May). Sex and spectacle in seventeen magazine: A feminist myth analysis [Paper presentation]. Meeting of the International Communication Association, San Francisco, CA. https:// doi.org/10.17077/s8b2-ukgu

Eagly, A. H. (1987). Sex differences in social behavior: A social role orientation. Lawrence Erlbaum.

Eagly, A. H., \& Wood, W. (1999). The origins of sex differences in human behavior: Evolved dispositions versus social roles. American Psychologist, 54, 408-423. https://doi.org/10.1037/0003-066X.54.6. 408

Erickson, R. J. (1993). Reconceptualizing family work: The effect of emotion work on perceptions of marital quality. Journal of Marriage and Family, 55, 888-900. https://doi.org/10.2307/352770

Erickson, R. J. (2005). Why emotion work matters: Sex, gender, and the division of household labor. Journal of Marriage and Family, 67, 337-351. https://doi.org/10.1111/j.0022-2445.2005.00120.x

Estes, S. B., Noonan, M. C., \& Maume, D. J. (2007). Is work-family policy use related to the gendered division of housework? Journal of Family and Economic Issues, 28, 527-545. https://doi.org/10.1007/ s10834-007-9075-6

Fahs, B. (2010). Radical refusals: On the anarchist politics of women choosing asexuality. Sexualities, 13, 445-461. https://doi.org/10. $1177 / 1363460710370650$

Fahs, B. (2011). Dreaded "otherness": Heteronormative patrolling in women's body hair rebellions. Gender and Society, 25, 451-472. https://doi.org/10.1177/0891243211414877

Fahs, B. (2014a). 'Freedom to' and 'freedom from': A new vision for sex-positive politics. Sexualities, 17, 267-290. https://doi.org/10. $1177 / 1363460713516334$

Fahs, B. (2014b). Genital panics: Constructing the vagina in women's qualitative narratives about pubic hair, menstrual sex, and vaginal self-image. Body Image, 11, 210-218. https://doi.org/10.1016/j. bodyim.2014.03.002

Fahs, B. (2014c). Coming to power: Women's fake orgasms and best orgasm experiences illuminate the failures of (hetero)sex and the pleasures of connection. Culture, Health and Sexuality, 16, 974 988. https://doi.org/10.1080/13691058.2014.924557

Fahs, B., \& Plante, R. (2017). On 'good sex' and other dangerous ideas: Women narrate their joyous and happy sexual encounters. Journal 
of Gender Studies, 26, 33-44. https://doi.org/10.1080/09589236. 2016.1246999

Farvid, P., Braun, V., \& Rowney, C. (2016). 'No girl wants to be called a slut!': Women, heterosexual casual sex and the sexual double standard. Journal of Gender Studies, 26, 544-560. https://doi.org/ 10.1080/09589236.2016.1150818

Fausto-Sterling, A. (2000). Sexing the body: Gender politics and the construction of sexuality. Basic Books.

Fennell, J. L. (2011). Men bring condoms, women take pills: Men's and women's roles in contraceptive decision making. Gender and Society, 25, 496-521. https://doi.org/10.1177/0891243211416113

Fernandez-Duque, E., Valeggia, C. R., \& Mendoza, S. P. (2009). The biology of paternal care in human and nonhuman primates. Annual Review of Anthropology, 38, 115-130. https://doi.org/10.1146/annur ev-anthro-091908-164334

Ferree, M. M. (1990). Beyond separate spheres: Feminism and family research. Journal of Marriage and Family, 52, 866-884. https:// doi.org/10.2307/353307

Fine, M. (1988). Sexuality, schooling, and adolescent females: The missing discourse of desire. Harvard Educational Review, 58, 29-54. https:// doi.org/10.17763/haer.58.1.u0468k1v2n2n8242

Finkelhor, D., Hotaling, G., Lewis, I. A., \& Smith, C. (1990). Sexual abuse in a national survey of adult men and women: Prevalence, characteristics, and risk factors. Child Abuse and Neglect, 14, 19-28. https:// doi.org/10.1016/0145-2134(90)90077-7

Fischer, A. R., \& Good, G. E. (2004). Women's feminist consciousness, anger, and psychological distress. Journal of Counseling Psychology, 51, 437-446. https://doi.org/10.1037/0022-0167.51.4.437

Fisher, H. E. (1992). Anatomy of love: The natural history of monogamy, adultery, and divorce. Simon \& Schuster.

Fodor, É., Gregor, A., Koltai, J., \& Kováts, E. (2020). The impact of COVID-19 on the gender division of childcare work in Hungary. European Societies, 23, S95-S110. https://doi.org/10.1080/14616 696.2020.1817522

Fortenberry, J. D., Tu, W., Harezlak, J., Katz, B. P., \& Orr, D. P. (2002). Condom use as a function of time in new and established adolescent sexual relationships. American Journal of Public Health, 92, 211-213. https://doi.org/10.2105/ajph.92.2.211

Frank, E., Anderson, C., \& Rubinstein, D. (1978). Frequency of sexual dysfunction in "normal" couples. New England Journal of Medicine, 299, 111-115. https://doi.org/10.1056/NEJM197807202990302

Fredrickson, B. L., \& Roberts, T.-A. (1997). Objectification theory: Toward understanding women's lived experiences and mental health risks. Psychology of Women Quarterly, 21, 173-306. https://doi.org/ 10.1111/j.1471-6402.1997.tb00108.x

Friedman, A., Weinberg, H., \& Pines, A. M. (1998). Sexuality and motherhood: Mutually exclusive in perception of women. Sex Roles, 38, 781-800. https://doi.org/10.1023/A:1018873114523

Frith, H. (2013). Labouring on orgasms: Embodiment, efficiency, entitlement and obligations in heterosex. Culture, Health and Sexuality, 15, 494-510. https://doi.org/10.1080/13691058.2013.767940

Frith, H. (2015). Sexercising to orgasm: Embodied pedagogy and sexual labour in women's magazines. Sexualities, 18, 310-328. https://doi. org $/ 10.1177 / 1363460714550912$

Frost, R. N., \& Donovan, C. L. (2015). Low sexual desire in women: Amongst the confusion, could distress hold the key? Sexual and Relationship Therapy, 30, 338-350. https://doi.org/10.1080/14681 994.2015.1020292

Frühauf, S., Gerger, H., Schmidt, H. M., Munder, T., \& Barth, J. (2013). Efficacy of psychological interventions for sexual dysfunction: A systematic review and meta-analysis. Archives of Sexual Behavior, 42, 915-933. https://doi.org/10.1007/s10508-012-0062-0

Fudge, M. C., \& Byers, E. S. (2017). "I have a nice gross vagina": Understanding young women's genital self-perceptions. Journal of Sex Research, 54, 351-361. https://doi.org/10.1080/00224499.2016. 1155200
Fugl-Meyer, S. K., \& Fugl-Meyer, A. R. (2002). Sexual disabilities are not singularities. International Journal of Impotence Research, 14, 487-493. https://doi.org/10.1038/sj.ijir.3900914

Fujimura, J. H. (2006). Sex genes: A critical sociomaterial approach to the politics and molecular genetics of sex determination. Signs, 32, 49-82. https://doi.org/10.1086/505612

Gailey, J. A. (2012). Fat shame to fat pride: Fat women's sexual and dating experiences. Fat Studies, 1, 114-127. https://doi.org/10.1080/ 21604851.2012.631113

Galupo, M. P., Davis, K. S., Grynkiewicz, A. L., \& Mitchell, R. C. (2014). Conceptualization of sexual orientation identity among sexual minorities: Patterns across sexual and gender identity. Journal of Bisexuality, 14, 433-456. https://doi.org/10.1080/15299716.2014. 933466

Gay, C. L., Lee, K. A., \& Lee, S.-Y. (2004). Sleep patterns and fatigue in new mothers and fathers. Biological Research for Nursing, 5, 311-318. https://doi.org/10.1177/1099800403262142

Gettler, L. T., \& Oka, R. C. (2016). Aging US males with multiple sources of emotional social support have low testosterone. Hormones and Behavior, 78, 32-42. https://doi.org/10.1016/j.yhbeh.2015.10.003

Gill, R. (2007). Postfeminist media culture: Elements of a sensibility. European Journal of Cultural Studies, 10, 147-166. https://doi.org/10. $1177 / 1367549407075898$

Gill, R. (2008). Empowerment/sexism: Figuring female sexual agency in contemporary advertising. Feminism and Psychology, 18, 35-60. https://doi.org/10.1177/0959353507084950

Gill, R. (2009). Mediated intimacy and postfeminism: A discourse analytic examination of sex and relationships advice in a women's magazine. Discourse and Communication, 3, 345-369. https://doi.org/ $10.1177 / 1750481309343870$

Glick, P., \& Fiske, S. T. (1996). The ambivalent sexism inventory: Differentiating hostile and benevolent sexism. Journal of Personality and Social Psychology, 70, 491-512. https://doi.org/10.1037/00223514.70.3.491

Goldey, K. L., Posh, A. R., Bell, S. N., \& van Anders, S. M. (2016). Defining pleasure: A focus group study of solitary and partnered sexual pleasure in queer and heterosexual women. Archives of Sexual Behavior, 45, 2137-2154. https://doi.org/10.1007/ s10508-016-0704-8

Goldey, K. L., \& van Anders, S. M. (2012). Sexual arousal and desire: Interrelations and responses to three modalities of sexual stimuli. Journal of Sexual Medicine, 9, 2315-2329. https://doi.org/10. 1111/j.1743-6109.2012.02845.x

Goldhammer, D. L., \& McCabe, M. P. (2011). A qualitative exploration of the meaning and experience of sexual desire among partnered women. Canadian Journal of Human Sexuality, 20, 19-29.

Gottschalk, M. (2008). Hiding in plain sight: American politics and the carceral state. Annual Review of Political Science, 11, 235-260. https://doi.org/10.1146/annurev.polisci.11.060606.135218

Grant, B. F., Chou, S. P., Saha, T. D., Pickering, R. P., Kerridge, B. T., Ruan, W. J., Huang, B., Jung, J., Zhang, H., Fan, A., \& Hasin, D. S. (2017). Prevalence of 12-month alcohol use, high-risk drinking, and DSM-IV alcohol use disorder in the United States, 2001-2002 to 2012-2013: Results from the national epidemiologic survey on alcohol and related conditions. JAMA Psychiatry, 74, 911-923. https://doi.org/10.1001/jamapsychiatry.2017.2161

Guez, M., Hildingsson, C., Nilsson, M., \& Toolanen, G. (2002). The prevalence of neck pain. Acta Orthopaedica Scandinavica, 73, 455-459. https://doi.org/10.1080/00016470216329

Günzler, C., \& Berner, M. M. (2012). Efficacy of psychosocial interventions in men and women with sexual dysfunctions-a systematic review of controlled clinical trials. Journal of Sexual Medicine, 9(12), 3108-3125. https://doi.org/10.1111/j.1743-6109.2012. 02965.x

Hamilton, L. D., \& Julian, A. M. (2014). The relationship between daily hassles and sexual function in men and women. Journal of Sex 
\& Marital Therapy, 40, 379-395. https://doi.org/10.1080/00926 23X.2013.864364

Hamilton, L. D., \& Meston, C. M. (2013). Chronic stress and sexual function in women. Journal of Sexual Medicine, 10, 2443-2454. https:// doi.org/10.1111/jsm.12249

Hammond, M. D., \& Overall, N. C. (2015). Benevolent sexism and support of romantic partner's goals: Undermining women's competence while fulfilling men's intimacy needs. Personality and Social Psychology Bulletin, 41, 1180-1194. https://doi.org/10.1177/01461 67215593492

Haraway, D. (1988). Situated knowledges: The science question in feminism and the privilege of partial perspective. Feminist Studies, 14, 575-599. https://doi.org/10.2307/3178066

Harding, S. G. (1986). From feminist empiricism to feminist standpoint epistemologies. In S. Harding (Ed.), The science question in feminism (pp. 136-162). Cornell University Press.

Harding, S. (1991). Whose science? Whose knowledge? Thinking from women's lives. Cornell University Press.

Harding, S. G. (2004). The feminist standpoint theory reader: Intellectual and political controversies. Routledge.

Harrell, W. A. (1995). Husbands' involvement in housework: Effects of relative earning power and masculine orientation. Psychological Reports, 77, 1331-1337. https://doi.org/10.2466/pr0.1995.77.3f. 1331

Hartley, H., \& Tiefer, L. (2003). Taking a biological turn: The push for a "female viagra" and the medicalization of women's sexual problems. Women's Studies Quarterly, 31, 42-54.

Hayfield, N., \& Clarke, V. (2012). "I'd be just as happy with a cup of tea": Women's accounts of sex and affection in long-term heterosexual relationships. Women's Studies International Forum, 35, 67-74. https://doi.org/10.1016/j.wsif.2012.01.003

Hays, S. (1996). The cultural contradictions of motherhood. Yale University Press.

Herbenick, D. (2009). Because it feels good: A woman's guide to sexual pleasure and satisfaction. Rodale.

Herbenick, D. (2019). Sexual pleasure, intimacy and (missed) connection: 10 years of the national survey of sexual health and behavior (NSSHB) [Conference presentation]. Meeting of the Society for Sex Therapy and Research, Toronto, Canada.

Herbenick, D., Bartelt, E., Fu, T.-C., Paul, B., Gradus, R., Bauer, J., \& Jones, R. (2019). Feeling scared during sex: Findings from a U.S. probability sample of women and men ages 14 to 60. Journal of Sex and Marital Therapy, 45, 424-439. https://doi.org/10.1080/00926 23X.2018.1549634

Herbenick, D., Fu, T.-C., Arter, J., Sanders, S. A., \& Dodge, B. (2018). Women's experiences with genital touching, sexual pleasure, and orgasm: Results from a U.S. probability sample of women ages 18 to 94. Journal of Sex and Marital Therapy, 44, 201-212. https://doi. org/10.1080/0092623X.2017.1346530

Herbenick, D., Fu, T., Valdivia, D. S., Patterson, C., Gonzalez, Y. R., Guerra-Reyes, L., Eastman-Mueller, H., Beckmeyer, J., \& Rosenberg, M. (2021). What is rough sex, who does it, and who likes it? Findings from a probability sample of U.S. undergraduate students. Archives of Sexual Behavior, 50, 1183-1195. https://doi.org/10. 1007/s10508-021-01917-w

Hinderliter, A. (2013). How is asexuality different from hypoactive sexual desire disorder? Psychology and Sexuality, 4, 167-178. https://doi. org/10.1080/19419899.2013.774165

Hintikka, J., Niskanen, L., Koivumaa-Honkanen, H., Tolmunen, T., Honkalampi, K., Lehto, S. M., \& Viinamäki, H. (2009). Hypogonadism, decreased sexual desire, and long-term depression in middle-aged men. Journal of Sexual Medicine, 6, 2049-2057. https:// doi.org/10.1111/j.1743-6109.2009.01299.x

Hochschild, A. R., \& Machung, A. (1989). The second shift: Working parents and the revolution at home. Viking.
Hoek, H. W., \& van Hoeken, D. (2003). Review of the prevalence and incidence of eating disorders. International Journal of Eating Disorders, 34, 383-396. https://doi.org/10.1002/eat.10222

Hogg-Johnson, S., van der Velde, G., Carroll, L. J., Holm, L. W., Cassidy, J. D., Guzman, J., Côté, P., Haldeman, S., Ammendolia, C., Carragee, E., Hurwitz, E., Nordin, M., \& Peloso, P. (2008). The burden and determinants of neck pain in the general population. European Spine Journal, 17, 39-51. https://doi.org/10.1007/s00586-008-0624-y

Horne, R. M., \& Johnson, M. D. (2019). A labor of love? Emotion work in intimate relationships. Journal of Social and Personal Relationships, 36, 1190-1209. https://doi.org/10.1177/0265407518756779

Hoskin, R. A. (2017). Femme theory: Refocusing the intersectional lens. Atlantis: Critical Studies in Gender. Culture and Social Justice, $38,95-109$.

Hudson, S. (2019, June 22). Race and sexual orientation's influence on gender prescriptive stereotypes [Conference presentation]. Society for the Psychological Study of Social Issues Conference, San Diego, CA, USA.

Humphreys, T. (2007). Perceptions of sexual consent: The impact of relationship history and gender. Journal of Sex Research, 44, 307-315. https://doi.org/10.1080/00224490701586706

Hyde, J. S. (2005). The gender similarities hypothesis. American Psychologist, 60, 581-592. https://doi.org/10.1037/0003-066X.60.6.581

Hyde, J. S. (2006). Gender similarities still rule. American Psychologist, 61, 641-642. https://doi.org/10.1037/0003-066X.61.6.641b

Hyde, J. S., Bigler, R. S., Joel, D., Tate, C. C., \& van Anders, S. M. (2019). The future of sex and gender in psychology: Five challenges to the gender binary. American Psychologist, 74, 171-193. https://doi.org/ 10.1037/amp0000307

Jackman, M. R. (1994). The velvet glove: Paternalism and conflict in gender, class, and race relations. University of California Press.

Jackson, A. L. (2015). State contexts and the criminalization of marital rape across the United States. Social Science Research, 51, 290-306. https://doi.org/10.1016/j.ssresearch.2014.10.001

Jackson, S. (2006). Interchanges: Gender, sexuality and heterosexuality: The complexity (and limits) of heteronormativity. Feminist Theory, 7, 105-121. https://doi.org/10.1177/1464700106061462

Jackson, S., \& Scott, S. (2002). Embodying orgasm. Women and Therapy, 24, 99-110. https://doi.org/10.1300/J015v24n01_13

Jagose, A. (1996). Queer theory: An introduction. NYU Press.

Jaspers, L., Feys, F., Bramer, W. M., Franco, O. H., Leusink, P., \& Laan, E. (2016). Efficacy and safety of flibanserin for the treatment of hypoactive sexual desire disorder in women: A systematic review and meta-analysis. JAMA Internal Medicine, 176, 453-462. https:// doi.org/10.1001/jamainternmed.2015.8565

Jeffreys, S. (2014). Beauty and misogyny: Harmful cultural practices in the west. Routledge.

Jenkins, A. L., Crann, S. E., Money, D. M., \& O’Doherty, K. C. (2018). "Clean and fresh": Understanding women's use of vaginal hygiene products. Sex Roles, 78, 697-709. https://doi.org/10.1007/ s11199-017-0824-1

Jerald, M. C., Ward, L. M., Moss, L., Thomas, K., \& Fletcher, K. D. (2017). Subordinates, sex objects, or sapphires? Investigating contributions of media use to black students' femininity ideologies and stereotypes about black women. Journal of Black Psychology, 43, 608-635. https://doi.org/10.1177/0095798416665967

Jockenhövel, F., Minnemann, T., Schubert, M., Freude, S., Hübler, D., Schumann, C., Christoph, A., \& Ernst, M. (2009). Comparison of long-acting testosterone undecanoate formulation versus testosterone enanthate on sexual function and mood in hypogonadal men. European Journal of Endocrinology, 160, 815-819. https://doi.org/ 10.1530/EJE-08-0830

Jordan-Young, R. M., \& Karkazis, K. (2019). Testosterone: An unauthorized biography. Harvard University Press. 
Kaestle, C. E., \& Allen, K. R. (2011). The role of masturbation in healthy sexual development: Perceptions of young adults. Archives of Sexual Behavior, 40, 983-994. https://doi.org/10.1007/s10508-010-9722-0

Kalichman, S. C., Williams, E. A., Cherry, C., Belcher, L., \& Nachimson, D. (1998). Sexual coercion, domestic violence, and negotiating condom use among low-income African American women. Journal of Women's Health, 7, 371-378. https://doi.org/10.1089/jwh.1998.7. 371

Kalmbach, D. A., Arnedt, J. T., Pillai, V., \& Ciesla, J. A. (2015). The impact of sleep on female sexual response and behavior: A pilot study. Journal of Sexual Medicine, 12, 1221-1232. https://doi.org/ 10.1111 jssm. 12858

Karatsoreos, I. N., \& McEwen, B. S. (2011). Psychobiological allostasis: Resistance, resilience and vulnerability. Trends in Cognitive Sciences, 15, 576-584. https://doi.org/10.1016/j.tics.2011.10.005

Karkazis, K., \& Jordan-Young, R. (2015). Debating a testosterone "sex gap." Science, 348, 858-860. https://doi.org/10.1126/science.aab10 57

Katz, J., \& Tirone, V. (2010). Going along with it: Sexually coercive partner behavior predicts dating women's compliance with unwanted sex. Violence against Women, 16, 730-742. https://doi.org/10.1177/ 1077801210374867

Kingsberg, S. A. (2002). The impact of aging on sexual function in women and their partners. Archives of Sexual Behavior, 31, 431-437. https:// doi.org/10.1023/a:1019844209233

Kyrölä, K. (2011). Adults growing sideways: Feederist pornography and fantasies of infantilism. Lambda Nordica, 16, 128-158.

Lam, J. C. W., Shields, G. S., Trainor, B. C., Slavich, G. M., \& Yonelinas, A. P. (2019). Greater lifetime stress exposure predicts blunted cortisol but heightened DHEA responses to acute stress. Stress and Health, 35, 15-26. https://doi.org/10.1002/smi.2835

Latshaw, B. A. (2015). From mopping to mowing: Masculinity and housework in stay-at-home father households. Journal of Men's Studies, 23, 252-270. https://doi.org/10.1177/1060826515600880

Laumann, E. O., Nicolosi, A., Glasser, D. B., Paik, A., Gingell, C., Moreira, E., \& Wang, T. (2005). Sexual problems among women and men aged 40-80 y: Prevalence and correlates identified in the Global Study of Sexual Attitudes and Behaviors. International Journal of Impotence Research, 17, 39-57. https://doi.org/10.1038/sj. ijir.3901250

Laumann, E. O., Paik, A., \& Rosen, R. C. (1999). Sexual dysfunction in the United States: Prevalence and predictors. Journal of the American Medical Association, 281, 537-544. https://doi.org/10.1001/jama. 281.6.537

Leavitt, C. E., Maurer, T. F., Clyde, T. L., Clarke, R. W., Busby, D. M., Yorgason, J. B., \& Holmes, S. J. (2021). Linking sexual mindfulness to mixed-sex couples' relational flourishing, sexual harmony, and orgasm. Archives of Sexual Behavior. https://doi.org/10.1007/ s10508-021-02054-01

Lee, D. Y., Kim, E., \& Choi, M. H. (2015). Technical and clinical aspects of cortisol as a biochemical marker of chronic stress. BMB Reports, 48, 209-216. https://doi.org/10.5483/BMBRep.2015.48.4.275

Leiblum, S. R. (2001). Women, sex and the internet. Sexual and Relationship Therapy, 16, 389-405. https://doi.org/10.1080/1468199012 6954

Lennon, K. (2019). Feminist perspectives on the body. In E. N. Zalta (Ed.), The Stanford encyclopedia of philosophy (Fall 2019). Metaphysics Research Lab, Stanford University. https://plato.stanford.edu/archi ves/fall2019/entries/feminist-body/

Levant, R. F., \& Richmond, K. (2008). A review of research on masculinity ideologies using the Male Role Norms Inventory. Journal of Men's Studies, 15, 130-146. https://doi.org/10.3149/jms.1502.130

Levin, I. (1972). The Stepford wives. Random House.

Levine, S. B. (2003). The nature of sexual desire: A clinician's perspective. Archives of Sexual Behavior, 32, 279-285. https://doi.org/10. 1023/a:1023421819465
Lindau, S. T., Schumm, L. P., Laumann, E. O., Levinson, W., O'Muircheartaigh, C. A., \& Waite, L. J. (2007). A study of sexuality and health among older adults in the United States. New England Journal of Medicine, 357, 762-774. https://doi.org/10.1056/NEJMo a067423

Ling, J., \& Kasket, E. (2016). Let's talk about sex: A critical narrative analysis of heterosexual couples' accounts of low sexual desire. Sexual and Relationship Therapy, 31, 325-343. https://doi.org/10. 1080/14681994.2016.1152357

Lloyd, E. A. (2009). The case of the female orgasm: Bias in the science of evolution. Harvard University Press.

Lockman, D. (2019). All the rage: Mothers, fathers, and the myth of equal partnership. HarperCollins.

Loe, M. (1999). Feminism for sale: Case study of a pro-sex feminist business. Gender and Society, 13, 705-732.

Loewenstein, G., Krishnamurti, T., Kopsic, J., \& McDonald, D. (2015). Does increased sexual frequency enhance happiness? Journal of Economic Behavior \& Organization, 116, 206-218. https://doi.org/ 10.1016/j.jebo.2015.04.021

Lopez-Aguado, P. (2016). The collateral consequences of prisonization: Racial sorting, carceral identity, and community criminalization. Sociology Compass, 10,12-23. https://doi.org/10.1111/soc4.12342

Lorber, J. (1994). Paradoxes of gender. Yale University Press.

Loving, T. J., Crockett, E. E., \& Paxson, A. A. (2009). Passionate love and relationship thinkers: Experimental evidence for acute cortisol elevations in women. Psychoneuroendocrinology, 34, 939-946. https://doi.org/10.1016/j.psyneuen.2009.01.010

Margolin, L., Moran, P. B., \& Miller, M. (1989). Social approval for violations of sexual consent in marriage and dating. Violence and Victims, 4, 45-55. https://doi.org/10.1891/0886-6708.4.1.45

Mark, K. P. (2014). The impact of daily sexual desire and daily sexual desire discrepancy on the quality of the sexual experience in couples. Canadian Journal of Human Sexuality, 23, 27-33. https://doi.org/ 10.3138/cjhs.23.1.A2

Mark, K. P., Herbenick, D., Fortenberry, D., Sanders, S., \& Reece, M. (2014). The object of sexual desire: Examining the "what" in "what do you desire?" Journal of Sexual Medicine, 11, 2709-2719. https:// doi.org/10.1111/jsm.12683

Mark, K. P., \& Murray, S. H. (2012). Gender differences in desire discrepancy as a predictor of sexual and relationship satisfaction in a college sample of heterosexual romantic relationships. Journal of Sex and Marital Therapy, 38, 198-215. https://doi.org/10.1080/ 0092623X.2011.606877

Masters, W. H., \& Johnson, V. (1966). Human sexual response. New York: Little Brown.

Mayor, E. (2015). Gender roles and traits in stress and health. Frontiers in Psychology. https://doi.org/10.3389/fpsyg.2015.00779

McCabe, M. P., Sharlip, I. D., Lewis, R., Atalla, E., Balon, R., Fisher, A. D., Laumann, E., Lee, S. W., \& Segraves, R. T. (2016). Incidence and prevalence of sexual dysfunction in women and men: A consensus statement from the Fourth International Consultation on Sexual Medicine 2015. Journal of Sexual Medicine, 13, 144-152. https:// doi.org/10.1016/j.jsxm.2015.12.034

McCaughey, M., \& French, C. (2001). Women's sex-toy parties: Technology, orgasm, and commodification. Sexuality and Culture, 5, 77-96. https://doi.org/10.1007/s12119-001-1031-2

McClelland, S. I. (2010). Intimate justice: A critical analysis of sexual satisfaction. Social and Personality Psychology Compass, 4, 663-680. https://doi.org/10.1111/j.1751-9004.2010.00293.x

McNulty, J. K., Maxwell, J. A., Meltzer, A. L., \& Baumeister, R. F. (2019). Sex-differentiated changes in sexual desire predict marital dissatisfaction. Archives of Sexual Behavior, 48, 2473-2489. https://doi. org/10.1007/s10508-019-01471-6

Mead, M. (1973). Coming of age in Samoa. Morrow. 
Meana, M. (2010). Elucidating women's (hetero)sexual desire: Definitional challenges and content expansion. Journal of Sex Research, 47, 104-122. https://doi.org/10.1080/00224490903402546

Meana, M., \& Nunnink, S. E. (2006). Gender differences in the content of cognitive distraction during sex. Journal of Sex Research, 43, 59-67. https://doi.org/10.1080/00224490609552299

Mears, A. (2014). Aesthetic labor for the sociologies of work, gender, and beauty. Sociology Compass, 8, 1330-1343. https://doi.org/10. $1111 /$ soc4.12211

Meixel, A., Yanchar, E., \& Fugh-Berman, A. (2015). Hypoactive sexual desire disorder: Inventing a disease to sell low libido. Journal of Medical Ethics, 41, 859-862. https://doi.org/10.1136/medet hics-2014-102596

Mercer, C. H., Fenton, K. A., Johnson, A. M., \& Wellings, K. (2003). Sexual function problems and help seeking behaviour in Britain: National probability sample survey. British Medical Journal, 327, 426. https://doi.org/10.1136/bmj.327.7412.426

Meucci, R. D., Fassa, A. G., \& Faria, N. M. X. (2015). Prevalence of chronic low back pain: Systematic review. Revista de Saúde Pública, 49, 1-10. https://doi.org/10.1590/S0034-8910.2015049005874

Meyer, I. H. (2003). Prejudice, social stress, and mental health in lesbian, gay, and bisexual populations: Conceptual issues and research evidence. Psychological Bulletin, 129, 674-697. https://doi.org/10. 1037/0033-2909.129.5.674

Miller, G. E., Chen, E., \& Zhou, E. S. (2007). If it goes up, must it come down? Chronic stress and the hypothalamic-pituitary-adrenocortical axis in humans. Psychological Bulletin, 133, 25-45. https://doi.org/ 10.1037/0033-2909.133.1.25

Monson, C. M., Langhinrichsen-Rohling, J., \& Binderup, T. (2000). Does "no" really mean "no" after you say "yes"?: Attributions about date and marital rape. Journal of Interpersonal Violence, 15, 1156-1174. https://doi.org/10.1177/088626000015011003

Montgomery-Downs, H., Stremler, R., \& Insana, S. (2013). Postpartum sleep in new mothers and fathers. The Open Sleep Journal, 6, 87-97. https://doi.org/10.2174/1874620901306010087

Moran, C., \& Lee, C. (2016). 'Everyone wants a vagina that looks less like a vagina': Australian women's views on dissatisfaction with genital appearance. Journal of Health Psychology, 23, 229-239.

Morokoff, P. J., \& Gillilland, R. (1993). Stress, sexual functioning, and marital satisfaction. Journal of Sex Research, 30, 43-53. https:// doi.org/10.1080/00224499309551677

Muehlenhard, C. L., Peterson, Z. D., Humphreys, T. P., \& Jozkowski, K. N. (2017). Evaluating the one-in-five statistic: Women's risk of sexual assault while in college. Journal of Sex Research, 54, 549-576. https://doi.org/10.1080/00224499.2017.1295014

Murray, S. H. (2019). Not always in the mood: The new science of men, sex, and relationships. Rowman \& Littlefield Publishers.

Murray, S. H., \& Milhausen, R. R. (2012). Sexual desire and relationship duration in young men and women. Journal of Sex \& Marital Therapy, 38, 28-40. https://doi.org/10.1080/0092623x.2011.569637

Nichols, M. (1983). The treatment of inhibited sexual desire (ISD) in lesbian couples. Women and Therapy, 1, 49-66. https://doi.org/10. 1300/J015V01N04_07

Nichols, M. (1988). Low sexual desire in lesbian couples. In S. R. Leiblum \& R. C. Rosen (Eds.), Sexual desire disorders (pp. 387-412). Guilford.

Nichols, M. (1995). Sexual desire disorder in a lesbian-feminist couple: The intersection of therapy and politics. In S. R. Leiblum \& R. C. Rosen (Eds.), Case studies in sex therapy (pp. 161-175). Guilford.

Nicolson, P., \& Burr, J. (2003). What is 'normal' about women's (hetero) sexual desire and orgasm?: A report of an in-depth interview study. Social Science \& Medicine, 57, 1735-1745. https://doi.org/10.1016/ S0277-9536(03)00012-1

Nobre, P. J., \& Pinto-Gouveia, J. (2008). Differences in automatic thoughts presented during sexual activity between sexually functional and dysfunctional men and women. Cognitive Therapy and Research, 32, 37-49. https://doi.org/10.1007/s10608-007-9165-7

O'Neil, J. M. (2008). Summarizing 25 years of research on men's gender role conflict using the Gender Role Conflict Scale: New research paradigms and clinical implications. The Counseling Psychologist, 36, 358-445. https://doi.org/10.1177/0011000008317057

Ogletree, S. M., \& Ginsburg, H. J. (2000). Kept under the hood: Neglect of the clitoris in common vernacular. Sex Roles, 43, 917-926. https:// doi.org/10.1023/A:1011093123517

Olson-Kennedy, J., Cohen-Kettenis, P. T., Kreukels, B. P. C., Meyer-Bahlburg, H. F. L., Garofalo, R., Meyer, W., \& Rosenthal, S, M. (2016). Research priorities for gender nonconforming/transgender youth: Gender identity development and biopsychosocial outcomes. Current Opinion in Endocrinology, Diabetes, and Obesity, 23, 172-179. https://doi.org/10.1097/MED.0000000000000236

Pacik, P. T. (2014). Understanding and treating vaginismus: A multimodal approach. International Urogynecology Journal, 25, 1613-1620. https://doi.org/10.1007/s00192-014-2421-y

Pain, R. (1991). Space, sexual violence and social control: Integrating geographical and feminist analyses of women's fear of crime. Progress in Human Geography, 15, 415-431. https://doi.org/10.1177/ 030913259101500403

Paterson, L. Q., Jin, E. S., Amsel, R., \& Binik, Y. M. (2014). Gender similarities and differences in sexual arousal, desire, and orgasmic pleasure in the laboratory. Journal of Sex Research, 51, 801-813. https://doi.org/10.1080/00224499.2013.867922

Payne, K. A., Reissing, E. D., Lahaie, M.-A., Binik, Y. M., Amsel, R., \& Khalifé, S. (2006). What is sexual pain? A critique of DSM's classification of dyspareunia and vaginismus. Journal of Psychology and Human Sexuality, 17, 141-154. https://doi.org/10.1300/J056v 17n03_10

Pepe, M. V., \& Byrne, T. J. (1991). Women's perceptions of immediate and long-term effects of failed infertility treatment on marital and sexual satisfaction. Family Relations, 40, 303-309. https://doi.org/ $10.2307 / 585016$

Pepping, C. A., Cronin, T. J., Lyons, A., \& Caldwell, J. G. (2018). The effects of mindfulness on sexual outcomes: The role of emotion regulation. Archives of Sexual Behavior, 47, 1601-1612. https:// doi.org/10.1007/s10508-017-1127-x

Petersen, J., \& Hyde, J. S. (2010). A meta-analytic review of research on gender differences in sexuality, 1993-2007. Psychological Bulletin, 136, 21-38. https://doi.org/10.1037/a0017504

Pfaus, J. G. (2009). Reviews: Pathways of sexual desire. Journal of Sexual Medicine, 6, 1506-1533. https://doi.org/10.1111/j.1743-6109.2009. 01309.x

Pleasants, R. K. (2011). Men learning feminism: Protecting privileges through discourses of resistance. Men and Masculinities, 14, 230 250. https://doi.org/10.1177/1097184X11407048

Prentice, D. A., \& Carranza, E. (2002). What women and men should be, shouldn't be, are allowed to be, and don't have to be: The contents of prescriptive gender stereotypes. Psychology of Women Quarterly, 26, 269-281. https://doi.org/10.1111/1471-6402.t01-1-00066

Raisanen, J. C., Chadwick, S. B., Michalak, N., \& van Anders, S. M. (2018). Average associations between sexual desire, testosterone, and stress in women and men over time. Archives of Sexual Behavior, 47, 1613-1631. https://doi.org/10.1007/s10508-018-1231-6

Rand, E. J. (2017). The right to be handsome: The queer sartorial objects of "masculine of center" fashion. QED: A Journal in GLBTQ Worldmaking, 4, 12-40.

Reece, M., Herbenick, D., \& Sherwood-Puzzello, C. (2004). Sexual health promotion and adult retail stores. Journal of Sex Research, 41, 173180. https://doi.org/10.1080/00224490409552225

Reinholtz, R. K., \& Muehlenhard, C. L. (1995). Genital perceptions and sexual activity in a college population. Journal of Sex Research, 32, 155-165. https://doi.org/10.1080/00224499509551785 
Rich, A. (1980). Compulsory heterosexuality and lesbian existence. Signs: Journal of Women in Culture and Society, 5, 631-660. https://doi. org/10.1086/493756

Richgels, P. B. (1992). Hypoactive sexual desire in heterosexual women. Women and Therapy, 12, 123-135. https://doi.org/10.1300/J015V 12N01_10

Ridley, C. A., Cate, R. M., Collins, D. M., Reesing, A. L., Lucero, A. A., Gilson, M. S., \& Almeida, D. M. (2006). The ebb and flow of marital lust: A relational approach. Journal of Sex Research, 43, 144-153.

Riordan, J. M., \& Rapp, E. T. (1980). Pleasure and purpose the sensuousness of breastfeeding. Journal of Obstetric, Gynecologic, and Neonatal Nursing, 9, 109-112. https://doi.org/10.1111/j.1552-6909. 1980.tb01317.x

Roberts, C., Kippax, S., Spongberg, M., \& Crawford, J. (1996). `Going down': Oral sex, imaginary bodies and HIV. Body and Society, 2, 107-124. https://doi.org/10.1177/1357034X96002003006

Robertson, L. G., Anderson, T. L., Hall, M. E. L., \& Kim, C. L. (2019). Mothers and mental labor: A phenomenological focus group study of family-related thinking work. Psychology of Women Quarterly, 43, 184-200. https://doi.org/10.1177/0361684319825581

Rosen, C. Brown, J. Heiman, S. Leiblum, C. Meston, R. Shabsigh, D. Ferguson, R., \& D'Agostino, R. (2000). The Female Sexual Function Index (FSFI): A multidimensional self-report instrument for the assessment of female sexual function. Journal of Sex \& Marital Therapy, 26, 191-208. https://doi.org/10.1080/ 009262300278597

Rubin, G. (1984). Thinking sex: Notes for a radical theory of the politics of sexuality. In C. S. Vance (Ed.), Pleasure and danger (pp. 143-178). Routledge.

Russell, D. E. H. (1990). Rape in marriage. Indiana University Press.

Salisbury, C. M. A., \& Fisher, W. A. (2014). "Did you come?" A qualitative exploration of gender differences in beliefs, experiences, and concerns regarding female orgasm occurrence during heterosexual sexual interactions. Journal of Sex Research, 51, 616-631. https:// doi.org/10.1080/00224499.2013.838934

Sanchez, D. T., Fetterolf, J. C., \& Rudman, L. A. (2012). Eroticizing inequality in the United States: The consequences and determinants of traditional gender role adherence in intimate relationships. Journal of Sex Research, 49, 168-183. https://doi.org/10.1080/00224499. 2011.653699

Sarrel, P. M. (1998). Ovarian hormones and vaginal blood flow: Using laser Doppler velocimetry to measure effects in a clinical trial of post-menopausal women. International Journal of Impotence Research, 10, S91-S93.

Sayer, L. C. (2005). Gender, time and inequality: Trends in women's and men's paid work, unpaid work and free time. Social Forces, 84, 285-303. https://doi.org/10.1353/sof.2005.0126

Schick, V. R., Calabrese, S. K., Rima, B. N., \& Zucker, A. N. (2010). Genital appearance dissatisfaction: Implications for women's genital image self-consciousness, sexual esteem, sexual satisfaction, and sexual risk. Psychology of Women Quarterly, 34, 394-404. https:// doi.org/10.1111/j.1471-6402.2010.01584.X

Schick, V. R., Zucker, A. N., \& Bay-Cheng, L. Y. (2008). Safer, better sex through feminism: The role of feminist ideology in women's sexual well-being. Psychology of Women Quarterly, 32, 225-232. https:// doi.org/10.1111/j.1471-6402.2008.00431.x

Schilt, K., \& Westbrook, L. (2009). Doing gender, doing heteronormativity. Gender and Society, 23, 440-464. https://doi.org/10.1177/ 0891243209340034

Schippers, M. (2007). Recovering the feminine other: Masculinity, femininity, and gender hegemony. Theory and Society, 36, 85-102. https://doi.org/10.1007/s11186-007-9022-4

Schreiner-Engel, P., Schiavi, R. C., White, D., \& Ghizzani, A. (1989). Low sexual desire in women: The role of reproductive hormones. Hormones and Behavior, 23, 221-234. https://doi.org/10.1016/ 0018-506X(89)90063-9
Schwartz, P. (1995). Love between equals: How peer marriage really works. Simon and Schuster.

Sedgwick, E. K. (1990). Epistemology of the closet. University of California Press.

Settles, I. H., \& Buchanan, N. T. (2014). Multiple groups, multiple identities, and intersectionality. In V. Benet-Martinez \& Y.-Y. Hong (Eds.), The Oxford handbook of multicultural identity (pp. 160-180). Oxford University Press.

Settles, I. H., Pratt-Hyatt, J. S., \& Buchanan, N. T. (2008). Through the lens of race: Black and white women's perceptions of womanhood. Psychology of Women Quarterly, 32, 454-468. https://doi.org/10. 1111/j.1471-6402.2008.00458.x

Shaw, S. M. (1985). Gender and leisure: Inequality in the distribution of leisure time. Journal of Leisure Research, 17, 266-282. https://doi. org/10.1080/00222216.1985.11969637

Shelton, B. A., \& John, D. (1993). Does marital status make a difference?: Housework among married and cohabiting men and women. Journal of Family Issues, 14, 401-420.

Shen, W. W., Urosevich, Z., \& Clayton, D. O. (1999). Sildenafil in the treatment of female sexual dysfunction induced by selective serotonin reuptake inhibitors. Journal of Reproductive Medicine, 44, 535-542.

Sims, K. E., \& Meana, M. (2010). Why did passion wane? A qualitative study of married women's attributions for declines in sexual desire. Journal of Sex and Marital Therapy, 36, 360-380. https://doi.org/ 10.1080/0092623X.2010.498727

Solmi, F., Hatch, S. L., Hotopf, M., Treasure, J., \& Micali, N. (2014). Prevalence and correlates of disordered eating in a general population sample: The South East London Community Health (SELCoH) Study. Social Psychiatry and Psychiatric Epidemiology, 49, 13351346. https://doi.org/10.1007/s00127-014-0822-3

Spector, I. P., Carey, M. P., \& Steinberg, L. (1996). The Sexual Desire Inventory: Development, factor structure, and evidence of reliability. Journal of Sex and Martial Therapy, 22, 175-190. https://doi.org/ 10.1080/00926239608414655

Stahl, S. M., Sommer, B., \& Allers, K. A. (2011). Multifunctional pharmacology of flibanserin: Possible mechanism of therapeutic action in hypoactive sexual desire disorder. Journal of Sexual Medicine, 8 , 15-27. https://doi.org/10.1111/j.1743-6109.2010.02032.x

Stephenson, K. R., \& Kerth, J. (2017). Effects of mindfulness-based therapies for female sexual dysfunction: A meta-analytic review. Journal of Sex Research, 54, 832-849. https://doi.org/10.1080/00224499. 2017.1331199

Sullivan, B. (2007). Rape, prostitution and consent. Australian \& New Zealand Journal of Criminology, 40, 127-142. https://doi.org/10. 1375/acri.40.2.127

Sun, C., Bridges, A., Wosnitzer, R., Scharrer, E., \& Liberman, R. (2008). A comparison of male and female directors in popular pornography: What happens when women are at the helm? Psychology of Women Quarterly, 32, 312-325. https://doi.org/10.1111/j.1471-6402.2008. 00439.x

Szymanski, D. M., Moffitt, L. B., \& Carr, E. R. (2010). Sexual objectification of women: Advances to theory and research. The Counseling Psychologist, 39, 6-38. https://doi.org/10.1177/0011000010378402

ter Kuile, M. M., Vigeveno, D., \& Laan, E. (2007). Preliminary evidence that acute and chronic daily psychological stress affect sexual arousal in sexually functional women. Behaviour Research and Therapy, 45, 2078-2089. https://doi.org/10.1016/j.brat.2007.03.006

Thébaud, S., Kornrich, S., \& Ruppanner, L. (2019). Good housekeeping, great expectations: Gender and housework norms. Sociological Methods \& Research. https://doi.org/10.1177/0049124119852395

Thompson, J. K., Heinberg, L. J., Altabe, M., \& Tantleff-Dunn, S. (1999). Exacting beauty: Theory, assessment, and treatment of body image disturbance. American Psychological Association. https://doi.org/ $10.1037 / 10312-000$ 
Thompson, L., \& Walker, A. J. (1989). Gender in families: Women and men in marriage, work, and parenthood. Journal of Marriage and Family, 51, 845-871. https://doi.org/10.2307/353201

Thrane, C. (2000). Men, women, and leisure time: Scandinavian evidence of gender inequality. Leisure Sciences, 22, 109-122. https://doi.org/ $10.1080 / 014904000272885$

Tiefer, L. (2000a). The social construction and social effects of sex research: The sexological model of sexuality. In C. B. Travis \& J. W. White (Eds.), Sexuality, society, and feminism (pp. 79-107). American Psychological Association. https://doi.org/10.1037/10345-004

Tiefer, L. (2000b). Sexology and the pharmaceutical industry: The threat of co-optation. Journal of Sex Research, 37, 273-283. https://doi. org/10.1080/00224490009552048

Tiefer, L. (2001). A new view of women's sexual problems: Why new? Why now? Journal of Sex Research, 38(2), 89-96.

Tiefer, L. (2004). Sex is not a natural act \& other essays. Avalon Publishing.

Tjaden, P., \& Thoennes, N. (2000). Prevalence and consequences of maleto-female and female-to-male intimate partner violence as measured by the national violence against women survey. Violence against Women, 6, 142-161. https://doi.org/10.1177/10778010022181769

Toates, F. (2009). An integrative theoretical framework for understanding sexual motivation, arousal, and behavior. Journal of Sex Research, 46, 168-193. https://doi.org/10.1080/00224490902747768

Tolman, D. L. (1994). Doing desire: Adolescent girls' struggles for/with sexuality. Gender and Society, 8, 324-342. https://doi.org/10.1177/ 089124394008003003

Tolman, D. L., \& Diamond, L. M. (2001). Desegregating sexuality research: Cultural and biological perspectives on gender and desire. Annual Review of Sex Research, 12, 33-74. https://doi.org/10.1080/ 10532528.2001.10559793

Tomiyama, A. J., Dallman, M. F., \& Epel, E. S. (2011). Comfort food is comforting to those most stressed: Evidence of the chronic stress response network in high stress women. Psychoneuroendocrinology, 36, 1513-1519. https://doi.org/10.1016/j.psyneuen.2011.04.005

Trudel, G., Marchand, A., Ravart, M., Aubin, S., Turgeon, L., \& Fortier, P. (2001). The effect of a cognitive-behavioral group treatment program on hypoactive sexual desire in women. Sexual and Relationship Therapy, 16, 145-164. https://doi.org/10.1080/14681 990120040078

Trudy. (2014, April 28). Explanation of misogynoir. Gradient Lair. https:// www.gradientlair.com/post/84107309247/define-misogynoir-antiblack-misogyny-moya-bailey-coined

van Anders, S. M. (2012). Testosterone and sexual desire in healthy women and men. Archives of Sexual Behavior, 41, 1471-1484. https://doi. org/10.1007/s10508-012-9946-2

van Anders, S. M. (2013). Beyond masculinity: Testosterone, gender/sex, and human social behavior in a comparative context. Frontiers in Neuroendocrinology, 34, 198-210. https://doi.org/10.1016/j.yfrne. 2013.07.001

van Anders, S. M. (2014). Bio/logics. TSQ: Transgender Studies Quarterly, 1, 33-35. https://doi.org/10.1215/23289252-2399524

van Anders, S. M. (2015). Beyond sexual orientation: Integrating gender/sex and diverse sexualities via Sexual Configurations Theory. Archives of Sexual Behavior, 44, 1177-1213. https://doi.org/10. 1007/s10508-015-0490-8

van Anders, S. M., \& Dunn, E. J. (2009). Are gonadal steroids linked with orgasm perceptions and sexual assertiveness in women and men? Hormones and Behavior, 56, 206-213. https://doi.org/10.1016/j. yhbeh.2009.04.007

van Anders, S. M., Goldey, K. L., \& Bell, S. N. (2014). Measurement of testosterone in human sexuality research: Methodological considerations. Archives of Sexual Behavior, 43, 231-250. https://doi.org/ 10.1007/s10508-013-0123-z

van Anders, S. M., Goldey, K. L., \& Kuo, P. X. (2011). The steroid/peptide theory of social bonds: Integrating testosterone and peptide responses for classifying social behavioral contexts. Psychoneuroendocrinology, 36, 1265-1275. https://doi.org/10.1016/j.psyne uen.2011.06.001

van Anders, S. M., Hamilton, L. D., Schmidt, N., \& Watson, N. V. (2007a). Associations between testosterone secretion and sexual activity in women. Hormones and Behavior, 51, 477-482. https://doi.org/10. 1016/j.yhbeh.2007.01.003

van Anders, S. M., Hamilton, L. D., \& Watson, N. V. (2007b). Multiple partners are associated with higher testosterone in North American men and women. Hormones and Behavior, 51, 454-459. https://doi. org/10.1016/j.yhbeh.2007.01.002

van Anders, S. M., Steiger, J., \& Goldey, K. L. (2015). Effects of gendered behavior on testosterone in women and men. Proceedings of the National Academy of Sciences of the United States of America, 112, 13805-13810. https://doi.org/10.1073/pnas.1509591112

van Anders, S. M., Tolman, R. M., \& Volling, B. L. (2012). Baby cries and nurturance affect testosterone in men. Hormones and Behavior, 61, 31-36. https://doi.org/10.1016/j.yhbeh.2011.09.012

van Anders, S. M., \& Watson, N. V. (2006). Social neuroendocrinology. Human Nature, 17, 212-237. https://doi.org/10.1007/ s12110-006-1018-7

van Hooff, J. H. (2011). Rationalising inequality: Heterosexual couples' explanations and justifications for the division of housework along traditionally gendered lines. Journal of Gender Studies, 20, 19-30. https://doi.org/10.1080/09589236.2011.542016

Vance, C. S. (1984). Pleasure and danger: Toward a politics of sexuality. In C. S. Vance (Ed.), Pleasure and danger: Exploring female sexuality (pp. 1-27). Routledge \& Kegan Paul.

Vohs, K. D., \& Baumeister, R. F. (2004). Sexual passion, intimacy, and gender. In D. J. Mashek \& A. Aron (Eds.), Handbook of closeness and intimacy (pp. 189-199). Lawrence Erlbaum Associates Publishers.

Waite, L. J., \& Gallagher, M. (2001). The case for marriage: Why married people are happier, healthier, and better off financially. Broadway Books.

Wakefield, J. C. (1997). Diagnosing DSM-IV_Part I: DSM-IV and the concept of disorder. Behaviour Research and Therapy, 35, 633-649. https://doi.org/10.1016/S0005-7967(97)00018-1

Wakefield, S., \& Wildeman, C. (2011). Mass imprisonment and racial disparities in childhood behavioral problems. Criminology and Public Policy, 10, 791-792. https://doi.org/10.1111/j.1745-9133. 2011.00741.x

Walters, P., \& Whitehouse, G. (2012). A limit to reflexivity: The challenge for working women of negotiating sharing of household labor. Journal of Family Issues, 33, 1117-1139. https://doi.org/10.1177/ $0192513 X 11431566$

Ward, L. M. (2016). Media and sexualization: State of empirical research, 1995-2015. Journal of Sex Research, 53, 560-577. https://doi.org/ 10.1080/00224499.2016.1142496

Ward, L. M., Jerald, M., Avery, L., \& Cole, E. R. (2020). Following their lead? Connecting mainstream media use to black women's gender beliefs and sexual agency. Journal of Sex Research, 57, 200-212. https://doi.org/10.1080/00224499.2018.1554741

Warner, M. (1991). Introduction: Fear of a queer planet. Social Text, 29, 3-17.

Waskul, D. D., Vannini, P., \& Wiesen, D. (2007). Women and their clitoris: Personal discovery, signification, and use. Symbolic Interaction, 30, 151-174. https://doi.org/10.1525/si.2007.30.2.151

West, C., \& Zimmerman, D. H. (1987). Doing gender. Gender and Society, 1, 125-151. https://doi.org/10.1177/0891243287001002002

Wiederman, M. W. (2000). Women's body image self-consciousness during physical intimacy with a partner. Journal of Sex Research, 37, 60-68. https://doi.org/10.1080/00224490009552021

Wiederman, M. W. (2005). The gendered nature of sexual scripts. The Family Journal, 13, 496-502. https://doi.org/10.1177/1066480705 278729 
Willis, M., \& Nelson-Gray, R. O. (2020). Setting a bad precedent: Sexual compliance in undergraduate women's sexually coercive relationships. Journal of American College Health. https://doi.org/10.1080/ 07448481.2020 .1732988

Witting, K., Santtila, P., Varjonen, M., Jern, P., Johansson, A., Von Der Pahlen, B., \& Sandnabba, K. (2008). Couples' sexual dysfunctions: Female sexual dysfunction, sexual distress, and compatibility with partner. Journal of Sexual Medicine, 5, 2587-2599. https://doi.org/ 10.1111/j.1743-6109.2008.00984.x

Woertman, L., \& van den Brink, F. (2012). Body image and female sexual functioning and behavior: A review. Journal of Sex Research, 49, 184-211. https://doi.org/10.1080/00224499.2012.658586

Wolf, N. (1990). The beauty myth. Chatto \& Windus.

Wood, J. M., Koch, P. B., \& Mansfield, P. K. (2006). Women's sexual desire: A feminist critique. Journal of Sex Research, 43, 236-244. https://doi.org/10.1080/00224490609552322

Wood, W., \& Eagly, A. H. (2002). A cross-cultural analysis of the behavior of women and men: Implications for the origins of sex differences.
Psychological Bulletin, 128, 699-727. https://doi.org/10.1037/ 0033-2909.128.5.699

Wood, W., \& Eagly, A. H. (2012). Biosocial construction of sex differences and similarities in behavior. In M. P. Zanna \& J. M. Olson (Eds.), Advances in experimental social psychology (Vol. 46, pp. 55-123). Elsevier. https://doi.org/10.1016/B978-0-12-394281-4.00002-7

Wright, K. P., Drake, A. L., Frey, D. J., Fleshner, M., Desouza, C. A., Gronfier, C., \& Czeisler, C. A. (2015). Influence of sleep deprivation and circadian misalignment on cortisol, inflammatory markers, and cytokine balance. Brain, Behavior, and Immunity, 47, 24-34. https:// doi.org/10.1016/j.bbi.2015.01.004

Yoder, J. D., Perry, R. L., \& Saal, E. I. (2007). What good is a feminist identity? Women's feminist identification and role expectations for intimate and sexual relationships. Sex Roles, 57, 365-372. https:// doi.org/10.1007/s11199-007-9269-2

Publisher's Note Springer Nature remains neutral with regard to jurisdictional claims in published maps and institutional affiliations. 